An Experimental and Modeling Study of Burning Velocities of Possible Future Synthetic Jet Fuels

Thomas Kick, Julia Herbst, Trupti Kathrotia, Jens Marquetand, Marina Braun-Unkhoff*, Clemens Naumann, Uwe Riedel

Energy, 43, (2012) pp. 111-123

The original publication is available at www.elsevier.com

http://dx.doi.org/10.1016/j.energy.2012.01.035 


\title{
An Experimental and Modeling Study of Burning Velocities of Possible Future Synthetic Jet Fuels
}

Th. Kick, J. Herbst, T. Kathrotia, J. Marquetand, M. Braun-Unkhoff*, C. Naumann, U. Riedel Institute of Combustion Technology, German Aerospace Center (DLR), Pfaffenwaldring 38-40, 70569 Stuttgart, Germany Corresponding author: Marina.Braun-Unkhoff@dlr.de

\begin{abstract}
Recently, the development of viable alternative aviation fuels has attracted much interest, for several reasons, with reduction of greenhouse gas (GHG) emissions and ensuring security of supply at affordable prices among them. In the present work, several alternative aviation fuels existing and potential - are investigated by focusing on their heat release: Gas-to-Liquid (GtL: representing a Fischer-Tropsch Synthetic Paraffinic Kerosene (FT-SPK)), a fully synthetic jet fuel (FSJF: Coal-to-Liquid (CtL)), and blends of GtL with 20\% 1-hexanol or 50\% naphthenic cut, respectively.

Burning velocities are measured at ambient pressures and at elevated preheat temperatures exploiting the cone angle method; equivalence ratios are between about $\varphi=1.0$ and $\varphi=1.4$. The measured data are used for the validation of a detailed chemical reaction model consisting of 4642 reactions involving 1075 species developed by Dagaut et al. [22-23] following the concept of a surrogate. The comparison between measured burning velocities and predicted laminar flame speeds shows reasonably good agreement with the model for the range of conditions considered in this study. The main features of the reaction model are also discussed, using sensitivity and rate of production analysis. Finally, the experimental data are compared with results obtained earlier for crude-oil kerosene. The findings support the potential of the investigated fuel mixtures to serve as alternative aviation fuels.
\end{abstract}

Keywords: Synthetic fuels, laminar flame speed, reaction modeling 


\section{Introduction}

Kerosene from crude-oil is the only jet fuel worldwide available since decades [1-2]. The total consumption of jet fuel was about 6.8 million barrels per day in 2007 and is forecasted to reach 7.6 million barrels per day in 2012 [3]. It is certified according to ASTM D1655 [4] if to be burnt during a flight. Hence, kerosene is the only fuel produced under very strict physical standards (energy content, freezing point, boiling point, viscosity, polarity, surface tension, minimum ignition temperature etc.) in order to cope with the demands of civil and military aviation.

The search for future alternatives has become a prominent topic within research and industry triggered by the impact of burning fossil fuels on climate and due to finite supplies. In addition, stricter emission policies have also made alternative fuels an active research topic.

Different targeted initiatives have been launched, in Europe as well as world-wide. The new energy policy agreed by the European Commission included a renewable energy roadmap proposing, among other measures, a binding $20 \%$ target for the overall share of renewable energy by 2020 . The aviation sector is also embedded in the EU policy package concerning renewable energy and $\mathrm{CO}_{2}$ emissions (Emission Trading Scheme, ETS), although jet fuels constitute presently only about $6 \%$ of the global oil consumption and about $2 \%$ of the overall $\mathrm{CO}_{2}$ emissions [5]. However, the air traffic is expected to increase further by about $5 \%$ per year [6].

For these reasons, the commercial aviation sector is looking into alternative solutions, such as blends or full substitution to kerosene, with a priority given to renewable fuels [7-10]. The Aviation Initiative for Renewable Energy in Germany (aireg) was announced in June 2011 as a platform for promoting sustainable jet fuel development [7]. IATA, the International Air Transport Association, has committed their vision of carbon neutral growth starting 2020 [8]. ACARE, the Advisory Council for Aeronautical Research in Europe, has set the goal of reducing $\mathrm{CO}_{2}$ emissions by $50 \%$ in 2050 compared to 2005, besides other [9]. In the U.S., several investigations are ongoing, e.g. the US "-Commercial Aviation Alternative Fuels Initiative-" (CAAFI) [10].

However, using alternative fuels in aeronautics is a great challenge. Aircraft engines need fuels that are very specific and very strict, with many severe constraints (e.g. freezing point of the fuel, energy density etc). As a consequence, synthetic aviation fuels must be characterized and certified, with respect to their physical and chemical properties, to ensure a safe and reliable operation for the whole flight envelope. Hence, a profound knowledge on jet fuel properties such as heat release or ignition delay time is inevitable, with respect to its technical specification.

Several flight and engine demonstrations with alternative fuels have been done over the last years; an overview is discussed in [11]. The first alternative jet fuel having been 
approved for commercial aviation was a CtL (Coal-to Liquid) fuel, developed by SASOL [12]. Then, a GtL (Gas-to-Liquid) fuel was developed [13]. Regarding BtL fuels (Biomass-toLiquid), potential feedstock can be biomass or biomass by-products, waste, algae or yeast. Until today, several demonstration flights are performed; in June 2011 Lufthansa has operated the first scheduled commercial flight worldwide with a biofuel [14-15]. However, it is still difficult to produce the amount of fuels needed for aviation.

Presently, a large number of feedstock, processes, and resulting products as well as a wide range of possible fuel candidates and fuel blends are being discussed [11, 16-17]. The main challenge is developing fuels that meet the very strict operational constraints in aviation (e.g. flight in very cold conditions), and that are compatible with current aircrafts, which is a must due to their long lifetime of 20-40 years.

In the context of the present work, four fuels are identified as possible alternative fuels to perform tests on engine components: CtL (as an example of a FSJF), GtL (as an example of a Fischer-Tropsch Synthetic Paraffinic Kerosene (FT-SPK), a blend of GtL $+50 \%$ naphthenic cut, and a blend of GtL $+20 \%$ 1-hexanol [16]. This fuel matrix offers the possibility to evaluate the potential of different chemical families (paraffinic - branched and unbranched, naphthenic, aromatic, and oxygenated compounds), reflecting the current discussion of potential fuels with respect to the short, middle, and long term view. Thus, the results will contribute to the future strategy for the use of alternative fuels for aircraft.

In the present work, burning velocities of the four fuel-air mixtures are measured in a newly constructed test rig, by applying the cone angle method [18-21]. The existing laminar high pressure burner concept is developed specifically for pre-vaporized liquid fuels. The experiments are performed at atmospheric pressure and at elevated preheat temperatures, for stoichiometric to rich equivalence ratios: $\varphi=1.0$ to 1.4. In addition to fuel-lean conditions, depending on the cycle, there are local zones in the combustor where fuel-rich conditions prevail, e.g. at the fuel injection port. The measured burning velocities are compared with laminar flame speeds predicted by a detailed reaction model from Dagaut et al. [22-23], in general, reasonably good agreement is found.

\section{Synthetic Fuels}

Similar to kerosene, any synthetic jet fuel must be characterized and certified, with respect to physical and chemical properties, to ensure a safe and reliable operation for the whole flight envelope [4]. Hence, it is of utmost importance to expand our knowledge on renewable jet fuels not only with respect to the experimental characterization of the fuel (technical specification) but also with respect to modeling capabilities enabling predictive CFD (computational fluid dynamics) simulations. Furthermore, any newly developed alternative jet 
fuel must be compatible with Jet A-1 due to the long lifetime cycle of aircraft engines ("dropin fuel").

To optimize synthetic jet fuel mixture applications in practical combustors, the combustion characteristics of these fuels must be well understood. One of the most important fundamental combustion characteristics of any fuel is its laminar flame speed, as a measure of the heat release. Its knowledge enables to avoid operating conditions where flashback may occur. The laminar flame speed has a direct impact on the flame length: depending on, the flame will stabilize at a certain height above the burner surface (HAB). In the technical system, if the laminar flame speed of an alternative fuel would differ from the one of Jet A-1, the heat load of the walls or recirculation zones might change. Such potential findings may have some impact on the design of the jet turbine burner and the combustion chamber. These data must be known reliably over a wide range of temperature, pressure, fuel composition, and fuel-air ratio. However, until now, only very limited data exist for synthetic jet fuels.

Synthetic fuels can be obtained from coal, gas, waste, and biomass gasification by Fischer-Tropsch (FT) processes. Synthetically manufactured fuels (synthetic kerosenes or FT-fuels) are considered as the only alternative jet fuels. For the midterm range, synthetic paraffinic kerosenes (SPK) from FT-process or hydro treatment blended in Jet A-1 seem to be the most promising alternative. In this context, BtL, HRJ (hydrogenated renewable jet), or HEFA (hydro processed esters and fatty acids) are the only ones to provide substantial progress regarding sustainability and $\mathrm{CO}_{2}$ emissions. In addition, future candidates to jet fuel could be new plant (or vegetable) oils or fatty acids, blended with kerosene. Kerosene and very high-quality diesel can be obtained by subsequent hydrocracking of the vegetable oil; industrial hydrogenation plants are under construction [24-25]. An interesting feature of modern hydrogenation processes is the possibility of influencing the length of the carbon chain (short or long molecules) as well as the chemical family of the products (branched or long-chained paraffines). This has an important influence on the physical properties of the resulting products such as cetane index and cold flow properties. Overall, the properties are similar to synthetic fuels produced in a FT-process [16].

\subsection{Fuel Selection}

Four synthetic fuel mixtures are selected for the experiments, as a result of the standard tests performed in [16]: a 100\% GtL fuel, a blend of GtL $+20(\mathrm{vol}) \%$ 1-hexanol, a blend of GtL+50(vol)\% naphthenic cut, and a 100\% CtL.

The fully synthetic jet fuel (FSJF) developed from Sasol [12] was chosen as the reference fuel. This fuel is the first fully synthetic fuel approved for commercial use in all types of turbine aircraft worldwide; thus, the FSJF is a "drop-in replacement" for kerosene from crude 
oil. The FSJF is produced from coal (CtL) applying the Fischer-Tropsch process. It consists of $50 \%$ FT-SPK and $50 \%$ of an aromatics-containing stream derived from severely hydrotreated coal tar kerosene. This product has a well-defined composition due to the fact that it comes from an identified refinery with a controlled process. Moreover, a synthetic fuel contains inherently less chemical families with a narrower distribution of components within each family, compared to Jet A-1/A $[12,16]$.

A GtL-fuel was chosen representing a FT-SPK as a promising alternative aviation fuel, as a neat product and in blends. The GtL used meets the SPK specification limits [26-27] and contains less than $0.5 \%$ (by mass) aromatics, whereas the ASTM D7655 specification indicate a minimum of around 8(vol)\% of aromatics in the final blend (Jet fuel + FT-SPK).

A blend of $\mathrm{GtL}+50 \%$ naphthenic cut was chosen due to the availability of the feedstock. The naphthenic or naphtheno-aromatic compounds can be produced from direct liquefaction of coal (nowadays) or sustainable from biomass (future). The naphthenic cut has some characteristics that seem to be suitable for jet fuel use: good cold flow properties as well as good energy content by volume. The main effect of adding naphthenic or naphthenoaromatic to FT-SPK is to bring the FT-SPK blend into the Jet A-1 specification limits (ASTM D7655) [26], mainly in terms of minimum aromatics content (8\% in volume) and density (minimum $775 \mathrm{~kg} \mathrm{~m}^{-3}$ ) [4, 16].

A blend of GtL $+20 \%$ 1-hexanol was chosen to investigate the influence of fuel molecules containing oxygen atoms, affecting fuel properties like: energy density, volatility, corrosion ability, material compatibility, and combustion properties. Presently fuel molecules containing oxygen atoms are not allowed in a jet fuel according to the specification [4]. However, such fuels might have some benefit as the oxygen might lead to the reduction of particulate emissions [28]. The smaller simple alcohols such as ethanol are less preferred to be used in aeronautics due to their mixing inability with aviation fuels. However, larger alcohols - such as butanol, 1-pentanol, and 1-hexanol - have better mixing capabilities due to their long alkyl carbon chain $[16,29]$. Thus, it is attractive to study them, in particular with respect to some physical properties such as energy density, flash point, water solubility, compared to the specified jet fuel properties $[11,16]$, avoiding some of the drawbacks of smaller alcohols such as ethanol. However, higher alcohols will only have a potential to be considered as a major component of alternative aviation fuels in the long term view if new production pathways will be developed. Currently, alcohols are produced from the fermentation of sugars by enzymes, without using the whole biomass.

\subsection{Fuel Mixtures Investigated}

The fuel mixtures investigated in the present work are summarized in Table 1. Four synthetic fuel mixtures are used for the experiments, a $100 \%$ GtL fuel $[16,27]$, a fuel 
containing GtL $+20 \%$ 1-hexanol $[16,29]$, a blend of GtL+50\% naphthenic cut $[16,29]$, and, for reference, a $100 \%$ CtL $[16,30]$. In the present work, the following surrogates are used as model fuels for all simulations: $n$-decane and iso-octane for GtL, with 1-hexanol included for GtL+20\% 1-hexanol [16, 31], and $n$-propylcyclohexane for GtL $+50 \%$ naphthenic cut, respectively, as shown in Table 1. To justify this choice of a surrogate, a detailed GC-MS analysis of the used fuels was conducted [32], to determine the chemical composition, given in Table 2. The major components of GtL fuel mixtures are $n$-decane and iso-octane. The same GtL mixtures (with 90.6\% $n$-decane and 9.4\% iso-octane) are used in the blends with 1-hexanol and naphthenic cut. The selection of surrogates (i.e. n-propylcyclohexane for naphthenic cut and $n$-propylbenzene in $\mathrm{CtL}$ ) is based on the studies conducted in [29, 31].

\section{Table 1}

Surrogates used for synthetic fuel-air mixtures.

\begin{tabular}{ccc}
\hline $\begin{array}{c}\text { Fuel [29, 31] } \\
\text { (measured) }\end{array}$ & Surrogate (modeling) $[16,22-23,31]$ \\
Species & mol\% \\
\hline Gas to Liquid (GtL) & $n$-decane & 90.6 \\
& iso-octane & 9.4 \\
\hline Gas to Liquid (GtL) & $n$-decane & 65.7 \\
+ & iso-octane & 6.8 \\
20 (vol)\% 1-hexanol & 1-hexanol & 27.5 \\
\hline Gas to Liquid (GtL) & n-decane & 45.3 \\
+ & iso-octane & 4.7 \\
50 (vol)\% naphthenic cut & $n$-propylcyclohexane & 50.0 \\
\hline Coal to Liquid (CtL) & $n$-decane & 72.0 \\
& iso-octane & 13.0 \\
& $n$-propylbenzene & 15.0 \\
\hline
\end{tabular}

Table 2 gives information on the chemical sum formula of the fuels studied and additionally the molecular weight and oxidizer to fuel ratio at $\varphi=1.0$. For GtL fuel, the chemical formula is $\mathrm{C}_{9.81} \mathrm{H}_{21.62}$ with an oxidizer to fuel ratio of 15.215 . The chemical sum formula of $\mathrm{GtL}+20 \%$ 1-hexanol mixture is $\mathrm{C}_{8.76} \mathrm{H}_{19.53} \mathrm{O}_{0.275}$, and the density is slightly lower than the one of Jet A-1 [16]. 


\section{Table 2}

Chemical sum formula for the modeled fuel-air mixtures [16, 22-23, 31].

\begin{tabular}{llll}
\hline Fuel & Formula & $\begin{array}{l}\mathrm{M} / \\
\mathrm{g} \mathrm{mol}^{-1}\end{array}$ & $\begin{array}{l}\mathrm{O}_{2} / \text { fuel (mole), } \\
\varphi=1.0\end{array}$ \\
& & & \\
\hline GtL & $\mathrm{C}_{9.81} \mathrm{H}_{21.62}$ & 139.3 & 15.215 \\
GtL+20\% 1-hexanol & $\mathrm{C}_{8.76} \mathrm{H}_{19.53} \mathrm{O}_{0.275}$ & 129.1 & 13.974 \\
GtL+50\% naphthenic cut & $\mathrm{C}_{9.406} \mathrm{H}_{19.81}$ & 132.7 & 14.359 \\
CtL & $\mathrm{C}_{9.59} \mathrm{H}_{19.98}$ & 135.1 & 14.585 \\
\hline
\end{tabular}

Some fundamental properties of these mixtures obtained from physical and chemical analysis [32] and of Jet A-1 such as density, elementary composition, flashpoint, viscosity, and heating values are given in Table 3. The chemical composition of the fuels investigated is determined by a GC-MS analysis [32]. A DB5-MS column (low bleeding) is used for this purpose with a length of $60 \mathrm{~m}$ and an internal diameter of $0.25 \mathrm{~mm}$. The chromatograms obtained can be considered as a finger print for a specific fuel mixture. For example, a GtL typically does not contain any aromatics, in contrast to Jet A-1, but long chained ( $n$-alkanes) and branched (iso-alkanes) alkanes as well as cyclic components (naphthenics). More details are discussed in [18]. The composition of the fuel blends is selected such that their properties are comparable to the ones of Jet A-1 fuel, thus fulfilling the criteria of a "drop-in" fuel.

\section{Table 3}

Properties (selected) of todays and potential future aviation fuels.

\begin{tabular}{|c|c|c|c|c|c|}
\hline $\begin{array}{l}\text { Fuels } \\
\text { Property }\end{array}$ & $\begin{array}{l}\text { Jet A-1 } \\
{[4]}\end{array}$ & $\begin{array}{l}\text { CtL } \\
{[32]}\end{array}$ & $\begin{array}{l}\text { GtL } \\
{[32]}\end{array}$ & $\begin{array}{l}\text { GtL+20\% } \\
\text { 1-hexanol [32] }\end{array}$ & $\begin{array}{l}\text { GtL }+50 \% \\
\text { naphthenic cut [32] }\end{array}$ \\
\hline Density & $775-840$ & 816 & 738 & 754 & 800 \\
\hline \multicolumn{6}{|l|}{ / kg m ${ }^{-3} @ 15^{\circ} \mathrm{C}$} \\
\hline C / \% mass & \multirow{2}{*}{$>99$} & 85.9 & 85.8 & 82.5 & 86.8 \\
\hline $\mathrm{H} / \%$ mass & & 13.0 & 14.8 & 14.1 & 13.6 \\
\hline O/\% mass & 0.0 & 0.0 & 0.0 & 3.6 & 0.0 \\
\hline Flashpoint & 38 & 57.5 & 48.5 & 46.5 & 57.0 \\
\hline $1{ }^{\circ} \mathrm{C}$ & minimum & & & & \\
\hline Heating value & 42800 & 42997 & 43242 & 42559 & 43373 \\
\hline$/ \mathrm{kJ} \mathrm{kg}^{-1}$ & minimum & & & & \\
\hline Viscosity & $0.80-0.88$ & 1.421 & 0.8296 & 1.026 & 1.415 \\
\hline I cSto @ $40^{\circ} \mathrm{C}$ & @ $20^{\circ} \mathrm{C}$ & & & & \\
\hline
\end{tabular}




\section{Experiments}

The burning velocities of vaporized liquid fuels are determined applying the commonly known cone angle method [33], as shown in Fig. 1. The concept of the existing burner system used previously for measuring the burning velocity of biogenic and synthetic gas mixtures [21, 34] was further engineered to use pre-vaporized liquid fuels in a newly constructed burner.
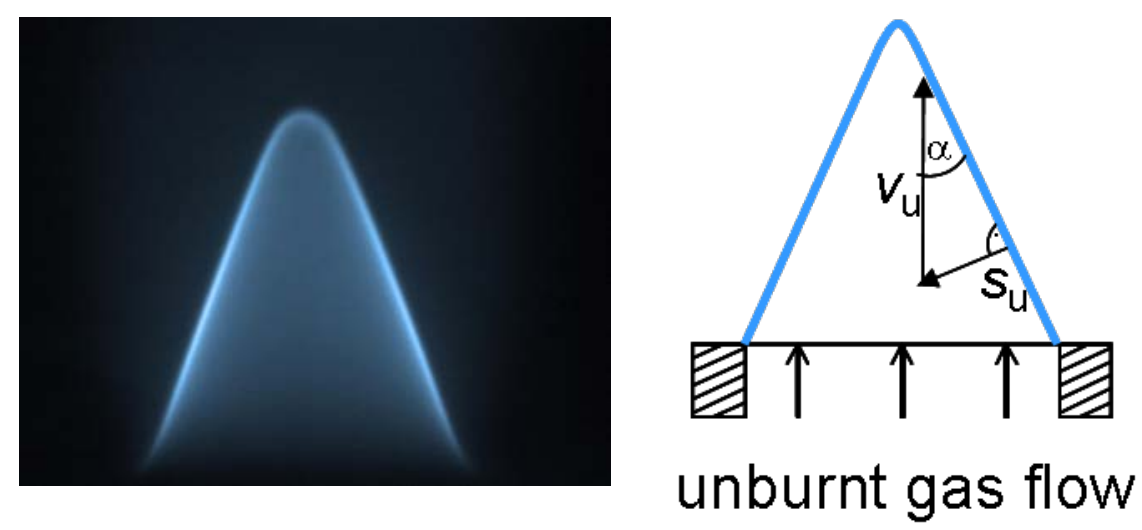

Fig. 1. Determination of the burning velocity by applying the cone angle method [33, 34].

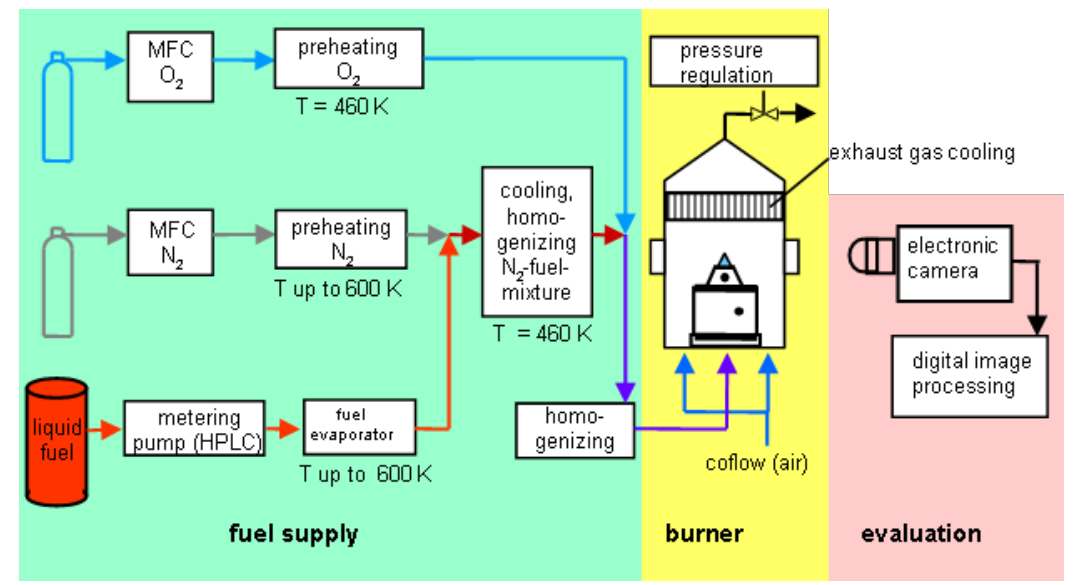

Fig. 2. The experimental setup.

\subsection{Experimental Setup}

The experimental setup used in the present work is shown schematically in Fig. 2. The main technical data of the burner are given in Table 4.

The facility consists of the burner housing with the flame holder, mass flow controllers (MFC, from Bronckhorst) for regulating oxygen and nitrogen flows, the fuel metering pump (HPLC pump, Shimadzu, Prominence LC-20AD), the fuel evaporator [35], and the homogenizing and the cooling section. The evaporator's main features are: mass flow up to $250 \mathrm{~g} \mathrm{~h}^{-1}$ (water), maximum vaporizing temperature of $670 \mathrm{~K}$, pressure up to 10 bar, and volume of the heated capillary system few cubic centimeters [35]. 
In order to avoid thermo-oxidative degradation, the fuel is deoxygenated by helium sparging. The fuel is vaporized at temperatures up to $600 \mathrm{~K}$ and mixed with the preheated nitrogen flow. Thermal degradation or cracking of the fuel is negligible at temperatures up to $600 \mathrm{~K}$ according to the study of Edwards and Atria [36]. They observed pyrolytic deposition from deoxygenated kerosenes starting at temperatures above $\sim 770 \mathrm{~K}$. This type of deposition appeared directly related to thermal cracking.

\section{Table 4}

Technical data of burner system.

\begin{tabular}{ll}
\hline Maximum pressure & Up to 40 bar \\
Optical access & $25 \mathrm{~mm}$ \\
$\begin{array}{l}\text { Maximum preheat } \\
\text { temperature }\end{array}$ & $520 \mathrm{~K}$ \\
Nozzles' material & Inconel \\
& Copper \\
Nozzles' orifice & $1.5-8.0 \mathrm{~mm}$ \\
\hline
\end{tabular}

Within the present work, the temperature of parts containing pure vaporized fuel or nitrogen is $570 \mathrm{~K}$. The ratio of nitrogen to oxygen flow is set to $79: 21$ (\%-vol.) in order to mimic fuel-air mixtures. After combining fuel and nitrogen flow, the mixture is cooled down to $460 \mathrm{~K}$ in order to avoid premature ignition before the oxygen is added. Then, the nitrogenfuel flow and the oxygen flow are mixed and homogenized. The parts containing nitrogen/oxygen (air) fuel mixtures are heated to $460 \mathrm{~K}$. By controlling temperature of the flame holder, the unburnt air fuel mixture is preheated to the desired value.

\subsection{Determining the Burning Velocity}

Premixed conical shaped flames are stabilized above nozzle flame holders. By changing the nozzle's diameter, flames with different air fuel ratios are realized. Digital images of the flames are captured with a CCD camera (La Vision, Imager Pro Plus 2M, 1200x1600 Pixel); from these images, contours are extracted and cone angles are calculated. The values of $S_{u}$ are derived from the cone angle $\alpha$ and the velocity $v_{u}$ of the unburnt gas based on the nozzle diameter and the volumetric flow rate (Fig. 1):

$$
S_{u}=v_{u} \cdot \sin \alpha \text {. }
$$




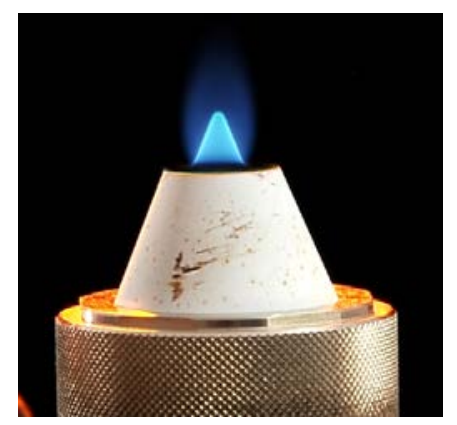

Fig. 3. Premixed conical flame: GtL/air, $\varphi=1.2$; suitable for obtaining $S_{u}$.

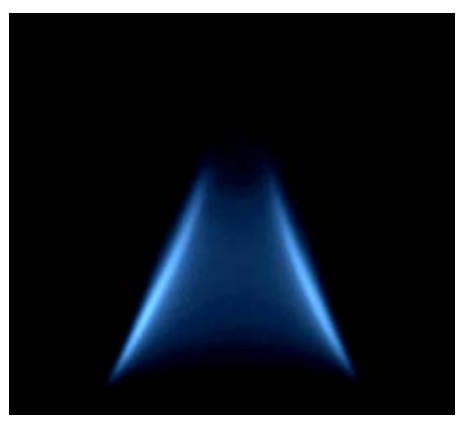

Fig. 4a. Premixed conical flame: $\varphi=1.5$; open tip.

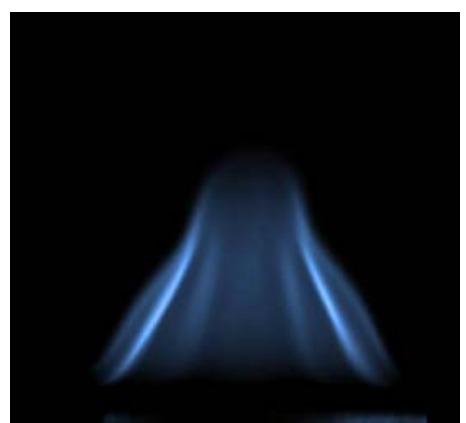

Fig. 4b. Premixed conical flame: $\varphi=1.55$; wrinkled contour.

Currently, conical flames can be stabilized at equivalence ratios from $\varphi$ about 0.95 up to $\varphi=1.4$ using nozzle diameters of $4 \mathrm{~mm}$ and $6 \mathrm{~mm}$. Figures 3 and 4 show typical flame shapes suitable (Fig. 3) and not suitable (Fig. 4) to determine burning velocities. At $\varphi<0.95$, flames are extinguished. Increasing the equivalence ratio $\varphi \geq 1.4$, the flame gets more and more unstable. Fluctuations of the flame cone lead to increasing standard deviations of the measured values. At $\varphi>1.5$, measurements of burning velocities are impossible because the flame tip is opened (Fig. 4a), or the contour is wrinkled (Fig. 4b).

The accuracy of the method is, on one hand, limited by deviations of the following values: temperature and mass flows of unburnt gases, determination of cone angles and pressure. The error of each of these values is in the order of 1 to $2 \%$, sum of the errors will be less than $5 \%$. On the other hand, there is the methodical error given by flame strain and curvature [37] and by possible deviation of flow pattern from ideal plug flow [20, 34, 38]. In [39], flame speeds obtained by various methods were compared, including nozzle burners with conical flames and button shaped flames, closed vessel combustors, and counter flow burners. Depending on heat conductivity and diffusivities of the components of the gas mixtures, flame speeds derived from the cone angle measurements might differ from those values obtained by more exact stretch corrected measurements. Markstein [40] proposed a relation between burning velocity and flame stretch. Vukadinovic et al. [41] have determined Markstein numbers of kerosene Jet A-1/air mixtures by means of spherical expanding flames for equivalence ratios between $\varphi=0.8$ and $\varphi=1.4$. The Markstein numbers, by which the flame stretch is quantified, are strongly depending on the equivalence ratio. Based on this work, our measurements might be up to $-15 \%$ lower compared to stretched corrected measurements, in the fuel rich regime $(\varphi=1.4)$. At stoichiometric conditions, our measured values of the burning velocities might be up to $+5 \%$ higher than the corrected values. In summary, the error bars in the Figs. 10, 12, 14, and 16 show the fluctuations of the individual measurements; they are standard deviations $( \pm \sigma)$. 


\section{Modeling}

\subsection{Combustion of Kerosene}

The chemical kinetic modeling of the combustion of kerosene is a challenging task. Its complex composition does not permit the complete development of a detailed reaction model which consists of all of the hundreds of different species and of all of the reactions that may occur between these species. Instead, a surrogate (or model-fuel) needs to be defined, with a limited number of compounds and known kinetic sub models as a means to represent real kerosene having numerous species [42]. Surrogates should show a behavior similar to that of commercial jet fuels, ideally having both the chemical and the physical properties of the real fuel. Such surrogates are of high interest since they can be utilized to study the effect of chemical composition and fuel properties on the combustion process. Presently, many proposals concerning the composition of a surrogate fuel exist; see for example [43-49].

Initial studies dealing with the combustion mechanism of practical fuels focused on simple hydrocarbon fuels, as practical fuels were too complex and not sufficiently defined in terms of chemical composition. Over the years, first, small hydrocarbons and aromatics were investigated and modeled; then, higher fuels such as $n$-decane [50-54], $n$-dodecane [55], and $n$-hexadecane [56]. Measurement of the ignition delay time of kerosene has been the subject of a few studies [1, 57-58], while some data exist for surrogates [42, 46-48, 58-60]. Higher alkanes, such as $n$-heptane $\left(n-\mathrm{C}_{7} \mathrm{H}_{16}\right)$, iso-octane $\left(i-\mathrm{C}_{8} \mathrm{H}_{18}\right)$, and $n$-decane $\left(n-\mathrm{C}_{10} \mathrm{H}_{22}\right)$ are important constituents of practical fuels $[43,58]$. Reaction mechanisms of $n-\mathrm{C}_{7} \mathrm{H}_{16}$ and iso$\mathrm{C}_{8} \mathrm{H}_{18}$ combustion are key parts in any kinetic model of reference fuels combustion [1, 58-60].

In this paper, the four different model fuels are studied as discussed earlier. The main surrogate components are $n$-decane (varying from 45 to $90 \%$ ) in addition to iso-octane, 1-hexanol, $n$-propylcyclohexane, and $n$-propylbenzene.

\subsection{The Reaction Model}

In the present work, the detailed chemical kinetic model used contains 1075 species and 4642 reactions, developed by Dagaut et al. [22-23, 31] and is validated for a wide variety of fuels. The transport data as well as the thermo dynamical data for the species involved in the reaction model are also taken from [22-23, 31]. The reaction model includes sub models of different chemical families typical for aviation fuels (long chain alkanes, branched alkanes, aromatics, naphthenes) and 1-hexanol. The reaction mechanism includes the sub mechanisms describing the oxidation of the fuel surrogates: $\mathrm{H}_{2} / \mathrm{O}_{2}, \mathrm{C}_{1}-\mathrm{C}_{10}$ hydrocarbons including the fuel surrogate components $n$-decane and iso-octane, aromatics (including $n$-propylbenzene), naphthenic species (also $n$-propylcyclohexane), and 1-hexanol. 
The predictive capability of this reaction model with respect to the laminar flame speed of the investigated synthetic fuel-air mixtures will be discussed below. It should be noted that for the simulations, surrogates will be used for representing the CtL and the GtL fuels.

The computation of the laminar premixed flame velocities are performed with the SANDIA code PREMIX [61] including thermal diffusion, for the assumption of a free flame. Typically, more than 100 grid points are used.

\subsection{Major Surrogates}

Rate of production analysis was performed with respect to the components of the surrogates of the fuels. Overall, the pattern is quite similar for all surrogates investigated at 1 bar pressure, $473 \mathrm{~K}$ preheat temperature and height above burner (HAB) where about $20 \%$ of the fuel is consumed.

\subsection{1. $n$-Decane}

Among all fuels studied, the $n$-decane is the major component ranging from $45 \%$ to about $90 \%$ (by mol) of the total fuel. The initiation reactions of the fuel $n$-decane $\left(n-\mathrm{C}_{10} \mathrm{H}_{22}\right)$ are thermal decomposition reactions in addition to the $\mathrm{H}$-abstraction reaction channel with $\mathrm{OH}$ radicals, $\mathrm{H}$ - and $\mathrm{O}$-atoms. The thermal decomposition produces two alkyl radicals whereas the $\mathrm{H}$-abstraction reactions produce five isomers of $n$-decyl radical $\left(i-\mathrm{C}_{10} \mathrm{H}_{21}\right)$ :

$$
\begin{aligned}
& n-\mathrm{C}_{10} \mathrm{H}_{22} \rightleftharpoons \mathrm{a}-\mathrm{C}_{5} \mathrm{H}_{11}+\mathrm{a}-\mathrm{C}_{5} \mathrm{H}_{11}, \\
& n-\mathrm{C}_{10} \mathrm{H}_{22} \rightleftharpoons \mathrm{p}-\mathrm{C}_{4} \mathrm{H}_{9}+\mathrm{a}-\mathrm{C}_{6} \mathrm{H}_{13}, \\
& n-\mathrm{C}_{10} \mathrm{H}_{22} \rightleftharpoons n-\mathrm{C}_{3} \mathrm{H}_{7}+\mathrm{a}-\mathrm{C}_{7} \mathrm{H}_{15}, \\
& n-\mathrm{C}_{10} \mathrm{H}_{22} \rightleftharpoons \mathrm{C}_{2} \mathrm{H}_{5}+\mathrm{a}-\mathrm{C}_{8} \mathrm{H}_{17}, \\
& \left.n-\mathrm{C}_{10} \mathrm{H}_{22}+\mathrm{R} \rightleftharpoons \mathrm{RH}+i-\mathrm{C}_{10} \mathrm{H}_{21} \quad \text { (where } \mathrm{R}=\mathrm{OH}, \mathrm{H}, \mathrm{O}, \mathrm{CH}_{3} \text { and } i=\mathrm{a}, \mathrm{b}, \ldots, \mathrm{e}\right) .
\end{aligned}
$$

In the CtL-air flame at a HAB of $0.18 \mathrm{~mm}$, the consumption channel of $n$-decane $(\varphi=1.0$, $T=473 \mathrm{~K}, p=1$ bar) is shown in Fig. 5 . The $\mathrm{H}$-abstraction of $n$-decane mainly with $\mathrm{R}=\mathrm{OH}$ and $\mathrm{H}$, forms five isomers of $n$-decyl radicals. The $n$-decyl radicals formed are isomerized:

$$
\begin{aligned}
& a-\mathrm{C}_{10} \mathrm{H}_{21} \rightleftharpoons d-\mathrm{C}_{10} \mathrm{H}_{21}, \\
& a-\mathrm{C}_{10} \mathrm{H}_{21} \rightleftharpoons e-\mathrm{C}_{10} \mathrm{H}_{21}, \\
& b-\mathrm{C}_{10} \mathrm{H}_{21} \rightleftharpoons d-\mathrm{C}_{10} \mathrm{H}_{21}, \\
& b-\mathrm{C}_{10} \mathrm{H}_{21} \rightleftharpoons e-\mathrm{C}_{10} \mathrm{H}_{21}, \\
& c-\mathrm{C}_{10} \mathrm{H}_{21} \rightleftharpoons d-\mathrm{C}_{10} \mathrm{H}_{21},
\end{aligned}
$$


$c-\mathrm{C}_{10} \mathrm{H}_{21} \rightleftharpoons e-\mathrm{C}_{10} \mathrm{H}_{21}$

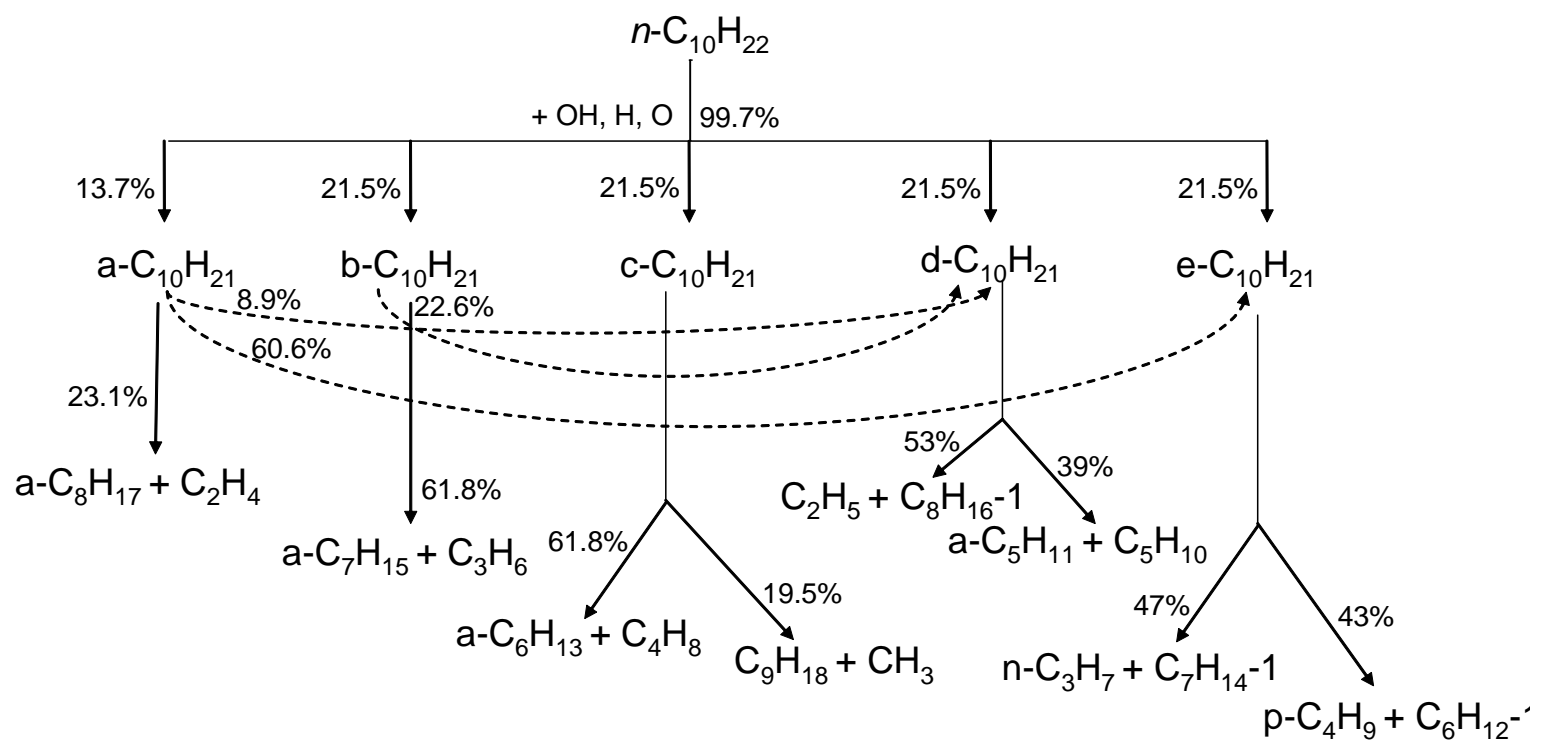

Fig. 5. Rate of production analysis: Schematic showing the consumption of $n$-decane in the CtL-air fuel mixture at $\mathrm{HAB}=0.18 \mathrm{~cm}\left(\varphi=1.0, p=1\right.$ bar, $\left.T_{0}=473 \mathrm{~K}\right)$.

Each of these $n$-decyl radicals formed decomposes to form mainly alkene and alkyl radicals which further react to smaller hydrocarbons such as $\mathrm{C}_{2} \mathrm{H}_{5}, \mathrm{C}_{2} \mathrm{H}_{4}$, and $\mathrm{C}_{2} \mathrm{H}_{3}$, the reaction pathways of which are well known. For all three GtL-air fuel mixtures, the rate of production analysis, performed at same conditions as for CtL, showed similar results.

\subsection{2. iso-Octane}

The rate of production analysis of iso-octane in CtL- and GtL-air mixtures revealed that in the flame front region, the dominant consumption channel of iso-octane is metathesis via $\mathrm{H}, \mathrm{OH}$ and to smaller extent via O-atoms and $\mathrm{CH}_{3}$; thus trimethyl-pentyl is formed:

$$
\begin{array}{ll}
\text { iso- } \mathrm{C}_{8} \mathrm{H}_{18}+\mathrm{R} \rightleftharpoons \mathrm{RH}+\text { 2,4,4-trimethyl-1-pentyl } & \text { (where } \mathrm{R}=\mathrm{OH}, \mathrm{H}, \mathrm{O}, \mathrm{CH}_{3} \text { ), } \\
\text { iso- } \mathrm{C}_{8} \mathrm{H}_{18}+\mathrm{R} \rightleftharpoons \mathrm{RH}+2,4,4 \text {-trimethyl-2-pentyl } & \text { (where } \mathrm{R}=\mathrm{OH}, \mathrm{H}, \mathrm{O}, \mathrm{CH}_{3} \text { ), } \\
\text { iso- } \mathrm{C}_{8} \mathrm{H}_{18}+\mathrm{R} \rightleftharpoons \mathrm{RH}+\text { 2,2,4-trimethyl-1-pentyl } & \text { (where } \mathrm{R}=\mathrm{OH}, \mathrm{H}, \mathrm{O}, \mathrm{CH}_{3} \text { ), } \\
\text { iso- } \mathrm{C}_{8} \mathrm{H}_{18}+\mathrm{R} \rightleftharpoons \mathrm{RH}+\text { 2,2,4-trimethyl-3-pentyl } & \text { (where } \mathrm{R}=\mathrm{OH}, \mathrm{H}, \mathrm{O}, \mathrm{CH}_{3} \text { ). }
\end{array}
$$




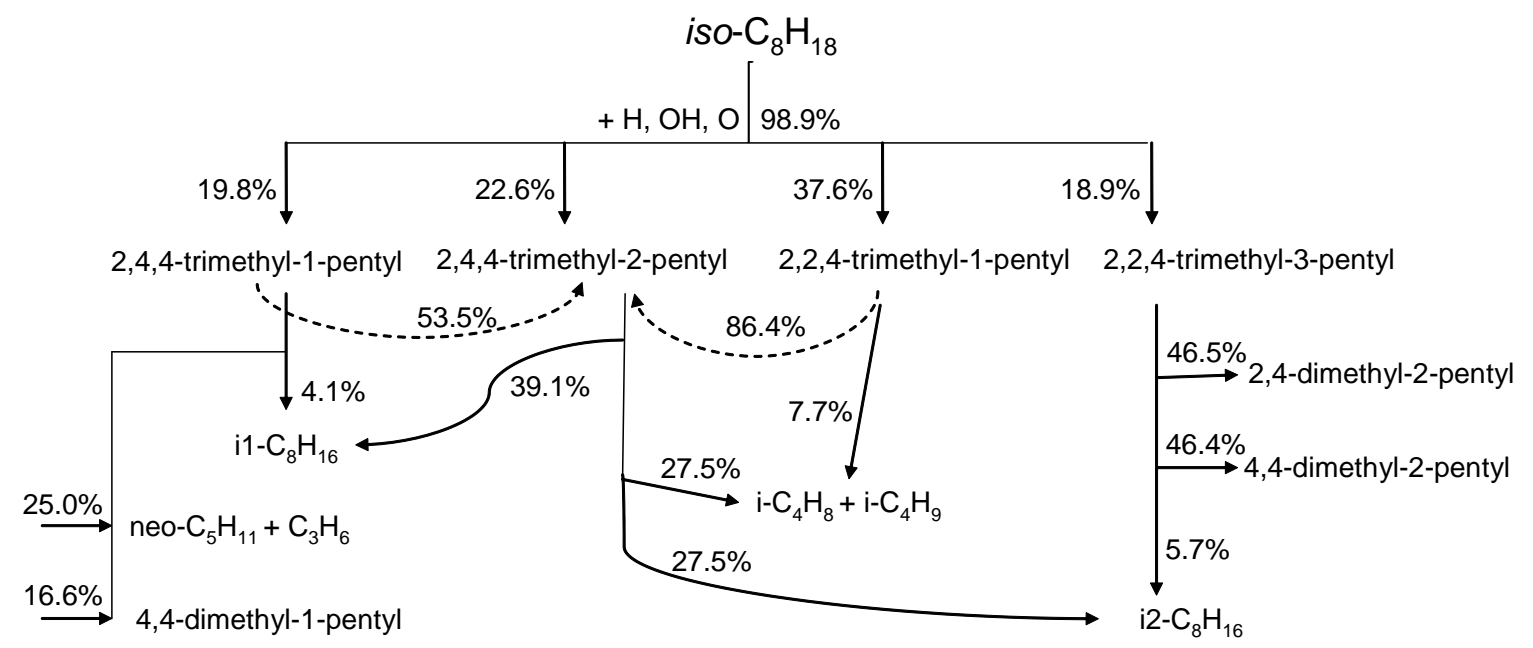

Fig. 6. Rate of production analysis: Schematic showing the consumption of iso-octane in the CtL-air fuel mixture at $\mathrm{HAB}=0.18 \mathrm{~cm}\left(\varphi=1.0, p=1 \mathrm{bar}, T_{0}=473 \mathrm{~K}\right)$.

As shown in Fig. 6, for the mixture of stoichiometric CtL-air, various trimethyl-pentyl formed are further decomposed yielding dimethyl-pentyl, neo- $\mathrm{C}_{5} \mathrm{H}_{11}, i-\mathrm{C}_{4} \mathrm{H}_{8}, i-\mathrm{C}_{4} \mathrm{H}_{9}$. These species formed result in the production of propene. The decomposition paths are quite similar to all of the three GtL-air fuels analyzed.

\subsubsection{1-Hexanol}

In the GtL-20\% 1-hexanol-air mixture, the surrogate 1-hexanol first reacts to hydroxyhexyl radicals $\left(i-\mathrm{C}_{6} \mathrm{H}_{12} \mathrm{OH}\right.$; where $i=1,2, \ldots, 6$ and is read as 1 -hydroxy-i-hexyl radical) by $\mathrm{H}$ atom abstraction reactions; these involve reaction of 1 -hexanol with $\mathrm{H}, \mathrm{OH}, \mathrm{O}$, $\mathrm{CH}_{3}$, and $\mathrm{CH}_{3} \mathrm{O}$ :

1-hexanol $+\mathrm{R} \rightleftharpoons i-\mathrm{C}_{6} \mathrm{H}_{12} \mathrm{OH}+\mathrm{RH} \quad$ (where $\mathrm{R}=\mathrm{H}, \mathrm{OH}, \mathrm{O}, \mathrm{CH}_{3}, \mathrm{CH}_{3} \mathrm{O}$, and $\mathrm{i}=1,2, \ldots, 6$ ).

The hydroxyhexyl radicals also inter-isomerize by the reactions:

$$
\begin{aligned}
1-\mathrm{C}_{6} \mathrm{H}_{12} \mathrm{OH} & \rightleftharpoons 4-\mathrm{C}_{6} \mathrm{H}_{12} \mathrm{OH}, \\
1-\mathrm{C}_{6} \mathrm{H}_{12} \mathrm{OH} & \rightleftharpoons 5-\mathrm{C}_{6} \mathrm{H}_{12} \mathrm{OH}, \\
1-\mathrm{C}_{6} \mathrm{H}_{12} \mathrm{OH} & \rightleftharpoons 6-\mathrm{C}_{6} \mathrm{H}_{12} \mathrm{OH}, \\
6-\mathrm{C}_{6} \mathrm{H}_{12} \mathrm{OH} & \rightleftharpoons 3-\mathrm{C}_{6} \mathrm{H}_{12} \mathrm{OH}, \\
6-\mathrm{C}_{6} \mathrm{H}_{12} \mathrm{OH} & \rightleftharpoons 2-\mathrm{C}_{6} \mathrm{H}_{12} \mathrm{OH}, \\
5-\mathrm{C}_{6} \mathrm{H}_{12} \mathrm{OH} & \rightleftharpoons 2-\mathrm{C}_{6} \mathrm{H}_{12} \mathrm{OH} .
\end{aligned}
$$


Figure 7 shows the rate of consumption for $\mathrm{GtL}+20 \% 1$-hexanol fuel mixture for the same condition as before ( $\left.p=1 \mathrm{bar}, \varphi=1.0, T_{0}=473 \mathrm{~K}, \mathrm{HAB}=0.08 \mathrm{~cm}\right)$. At this condition, 1-hexanol reacts via $\mathrm{H}$-atom abstraction reactions (mainly $\mathrm{R}=\mathrm{H}, \mathrm{OH}$ ) to hydroxyhexyl radicals. Isomerization reaction of $i-\mathrm{C}_{6} \mathrm{H}_{12} \mathrm{OH}$ also takes place. The hydroxyhexyl radicals further reacts to form aldehydes, alkene and alkyl radicals. Acetaldehyde $\left(\mathrm{CH}_{3} \mathrm{HCO}\right)$ and hexanal $\left(\mathrm{C}_{5} \mathrm{H}_{11} \mathrm{HCO}\right)$ are main products of $1-\mathrm{C}_{6} \mathrm{H}_{12} \mathrm{OH}$ decomposition. Smaller alcohols and alkyl radicals are formed in subsequent consumption reactions of $i-\mathrm{C}_{6} \mathrm{H}_{12} \mathrm{OH}$ :

$$
\begin{aligned}
& 2-\mathrm{C}_{6} \mathrm{H}_{12} \mathrm{OH} \rightleftharpoons \mathrm{C}_{2} \mathrm{H}_{3} \mathrm{CH}_{2} \mathrm{OH}+n-\mathrm{C}_{3} \mathrm{H}_{7}, \\
& 3-\mathrm{C}_{6} \mathrm{H}_{12} \mathrm{OH} \rightleftharpoons \mathrm{CH}_{2} \mathrm{OH}+\mathrm{C}_{5} \mathrm{H}_{10}, \\
& 6-\mathrm{C}_{6} \mathrm{H}_{12} \mathrm{OH} \rightleftharpoons \mathrm{CH}_{2} \mathrm{CH}_{2} \mathrm{CH}_{2} \mathrm{OH}+\mathrm{C}_{3} \mathrm{H}_{6} .
\end{aligned}
$$

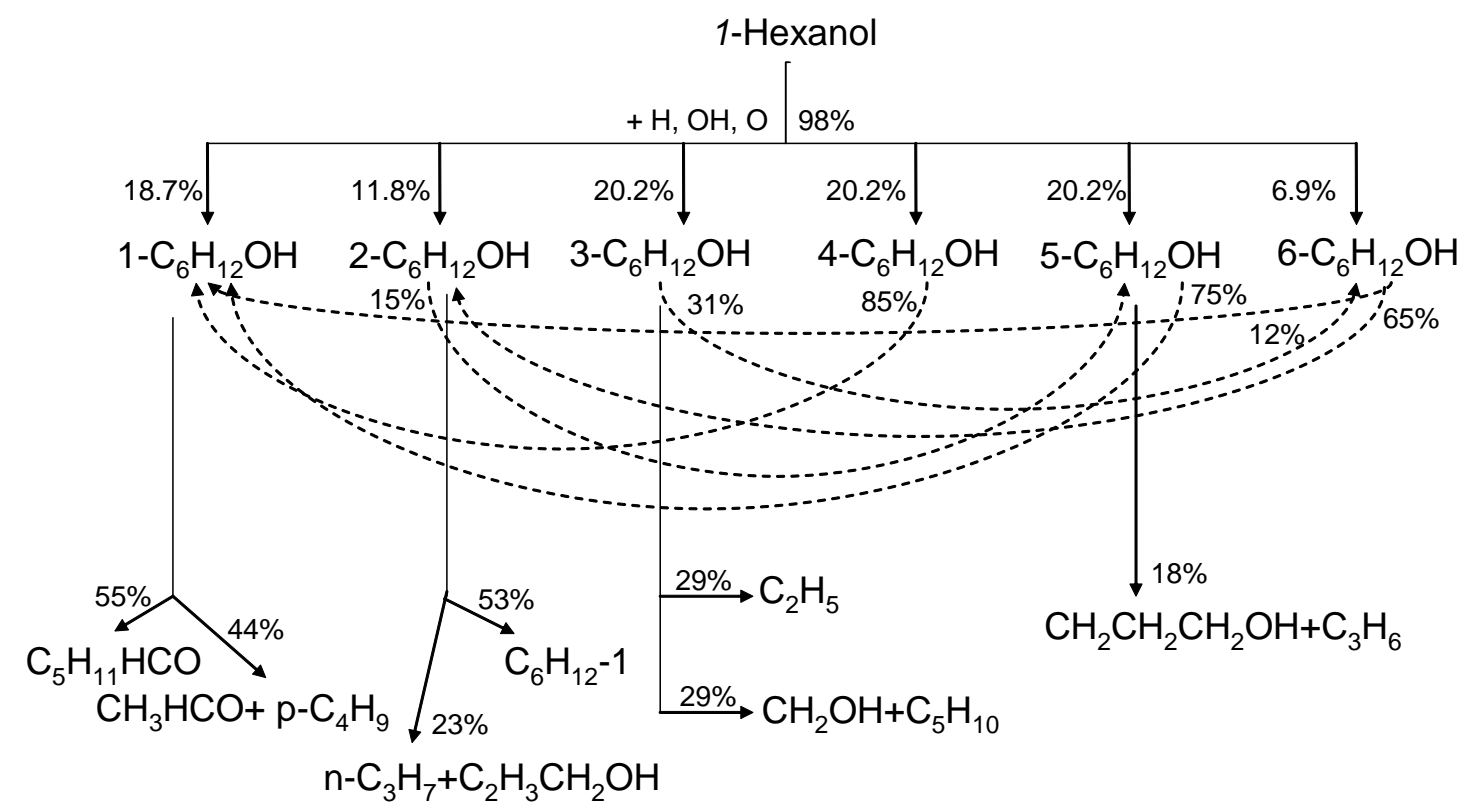

Fig. 7. Rate of production analysis: Schematic showing the consumption of 1-hexanol in the GtL+20\% 1-hexanol -air fuel mixture at $\mathrm{HAB}=0.08 \mathrm{~cm}\left(\varphi=1.0, p=1 \mathrm{bar}, T_{0}=473 \mathrm{~K}\right)$.

\subsection{4. n-Propylbenzene}

The CtL fuel contains 15\% n-propylbenzene $\left(\mathrm{C}_{6} \mathrm{H}_{5} \mathrm{C}_{3} \mathrm{H}_{7}\right)$ in the surrogate, besides $72 \%$ $n$-decane and $13 \%$ iso-octane. The initiation reactions of $n$-propylbenzene form phenylpropyl radicals $\left(i-\mathrm{C}_{6} \mathrm{H}_{5} \mathrm{C}_{3} \mathrm{H}_{6}\right.$, where $\left.i=\mathrm{a}, \mathrm{b}, \mathrm{c}\right)$ by $\mathrm{C}-\mathrm{H}$ bond breakage:

$$
\begin{aligned}
& \mathrm{C}_{6} \mathrm{H}_{5} \mathrm{C}_{3} \mathrm{H}_{7} \rightleftharpoons \mathrm{a}-\mathrm{C}_{6} \mathrm{H}_{5} \mathrm{C}_{3} \mathrm{H}_{6}+\mathrm{H}, \\
& \mathrm{C}_{6} \mathrm{H}_{5} \mathrm{C}_{3} \mathrm{H}_{7} \rightleftharpoons \mathrm{b}-\mathrm{C}_{6} \mathrm{H}_{5} \mathrm{C}_{3} \mathrm{H}_{6}+\mathrm{H}, \\
& \mathrm{C}_{6} \mathrm{H}_{5} \mathrm{C}_{3} \mathrm{H}_{7} \rightleftharpoons \mathrm{c}-\mathrm{C}_{6} \mathrm{H}_{5} \mathrm{C}_{3} \mathrm{H}_{6}+\mathrm{H} .
\end{aligned}
$$


Similar to the $n$-propylcyclohexane and the 1-hexanol sub mechanisms, the important reactions of propylbenzene oxidation involve formation of phenylpropyl radicals $\left(i-\mathrm{C}_{6} \mathrm{H}_{5} \mathrm{C}_{3} \mathrm{H}_{6}\right)$ by $\mathrm{H}$-abstraction reactions, with $\mathrm{R}=\mathrm{H}, \mathrm{O}, \mathrm{OH}, \mathrm{HO}_{2}, \mathrm{CH}_{3}$, and a few small hydrocarbons:

$$
\begin{aligned}
& \mathrm{C}_{6} \mathrm{H}_{5} \mathrm{C}_{3} \mathrm{H}_{7}+\mathrm{R} \rightleftharpoons \mathrm{a}-\mathrm{C}_{6} \mathrm{H}_{5} \mathrm{C}_{3} \mathrm{H}_{6}+\mathrm{RH}, \\
& \mathrm{C}_{6} \mathrm{H}_{5} \mathrm{C}_{3} \mathrm{H}_{7}+\mathrm{R} \rightleftharpoons \mathrm{b}-\mathrm{C}_{6} \mathrm{H}_{5} \mathrm{C}_{3} \mathrm{H}_{6}+\mathrm{RH}, \\
& \mathrm{C}_{6} \mathrm{H}_{5} \mathrm{C}_{3} \mathrm{H}_{7}+\mathrm{R} \rightleftharpoons \mathrm{c}-\mathrm{C}_{6} \mathrm{H}_{5} \mathrm{C}_{3} \mathrm{H}_{6}+\mathrm{RH} .
\end{aligned}
$$

Figure 8 shows the consumption channel of $n$-propylbenzene for the same conditions discussed before $\left(p=1\right.$ bar, $\left.\varphi=1.0, T_{0}=473 \mathrm{~K}, \mathrm{HAB}=0.18 \mathrm{~cm}\right)$. It can be seen that at this condition the major consumption of $\mathrm{C}_{6} \mathrm{H}_{5} \mathrm{C}_{3} \mathrm{H}_{7}$ is due to the $\mathrm{H}$-abstraction reaction dominantly by $\mathrm{R}=\mathrm{H}, \mathrm{OH}$ forming phenylpropyl radicals and the remaining fuel is consumed by the displacement of propyl by a $\mathrm{H}$-atom reaction forming benzene and propyl. The 3phenyl-1-propyl (a- $\left.\mathrm{C}_{6} \mathrm{H}_{5} \mathrm{C}_{3} \mathrm{H}_{6}\right)$ is consumed in reactions forming benzyl $\left(\mathrm{C}_{6} \mathrm{H}_{5} \mathrm{CH}_{2}\right)$ and $\mathrm{C}_{2} \mathrm{H}_{4}$ by ß-scission, and by phenyl shift 2-phenyl-1-propyl (b- $\mathrm{C}_{6} \mathrm{H}_{5}$ propyl) is formed from 1-phenyl2-propyl (b- $\mathrm{C}_{6} \mathrm{H}_{5} \mathrm{C}_{3} \mathrm{H}_{6}$ ) which further reacts to yield styrene and methyl. Styrene is also produced from 1-phenyl-1-propyl $\left(\mathrm{c}-\mathrm{C}_{6} \mathrm{H}_{5} \mathrm{C}_{3} \mathrm{H}_{6}\right)$ via ß-scission:

$$
\begin{aligned}
& \text { a- } \mathrm{C}_{6} \mathrm{H}_{5} \mathrm{C}_{3} \mathrm{H}_{6} \rightleftharpoons \mathrm{C}_{6} \mathrm{H}_{5} \mathrm{CH}_{2}+\mathrm{C}_{2} \mathrm{H}_{4}, \\
& \text { b- } \mathrm{C}_{6} \mathrm{H}_{5} \mathrm{C}_{3} \mathrm{H}_{6} \rightleftharpoons \text { b- } \mathrm{C}_{6} \mathrm{H}_{5} \text { propyl } \rightleftharpoons \text { styrene }+\mathrm{CH}_{3}, \\
& \text { c- } \mathrm{C}_{6} \mathrm{H}_{5} \mathrm{C}_{3} \mathrm{H}_{6} \rightleftharpoons \text { styrene }+\mathrm{CH}_{3} .
\end{aligned}
$$

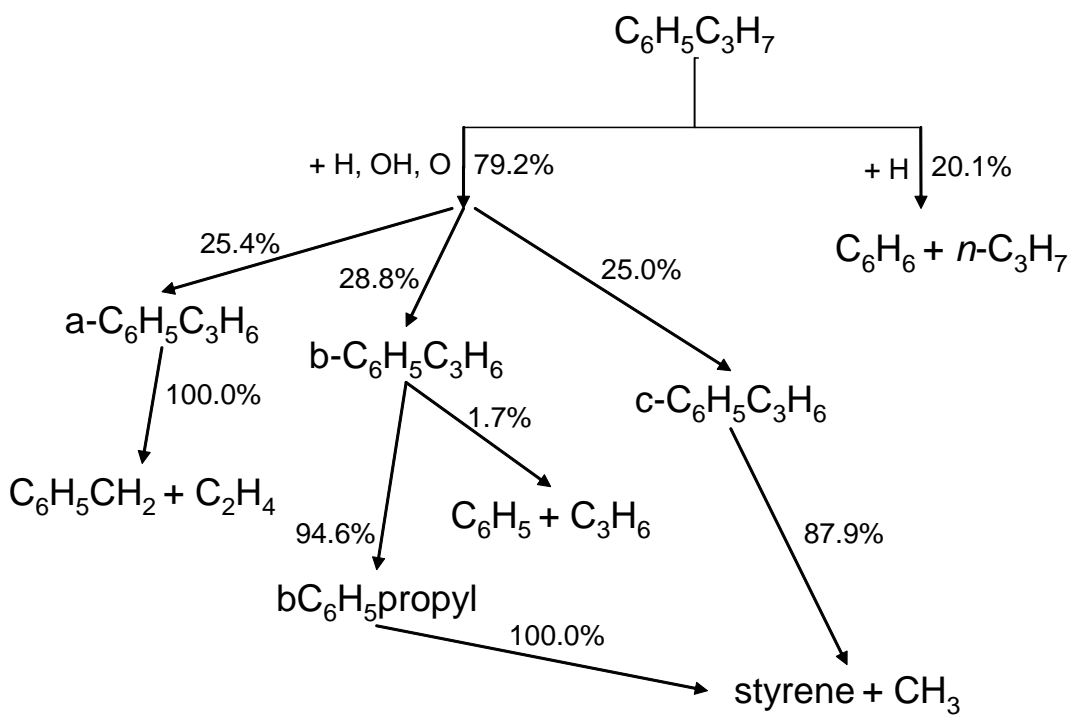

Fig. 8. Rate of production analysis: Schematic showing the consumption of $n$ - 
propylbenzene in the CtL-air fuel mixture at $\mathrm{HAB}=0.18 \mathrm{~cm}\left(\varphi=1.0, p=1 \mathrm{bar}, T_{0}=473\right.$ $\mathrm{K})$.

\subsection{5. n-Propylcyclohexane}

The major surrogate in the $\mathrm{GtL}+50 \%$ naphthenic cut mixture is $n$-propylcyclohexane, besides iso-octane and $n$-decane. The important reactions for the description of $n$-propylcyclohexane oxidation involve unimolecular reactions of $n$-propylcyclohexane leading to bond breaking in the alkyl chain and $\mathrm{C}-\mathrm{H}$ and $\mathrm{C}-\mathrm{C}$ bond on the cycle ( $n$-propylcyclohexane $\rightleftharpoons \mathrm{RCi}-\mathrm{C}_{9} \mathrm{H}_{17} \# 6+\mathrm{H}$ where $\mathrm{i}=1,2, \ldots, 7)$. Also important are the bimolecular $\mathrm{H}$-abstraction reactions of n-propylcyclohexane with $\mathrm{O}_{2}, \mathrm{H}, \mathrm{O}, \mathrm{OH}, \mathrm{HO}_{2}$, and $\mathrm{CH}_{3}$ forming cyclohexanepropyl radicals $\left(\right.$ RCi- ${ }_{9} \mathrm{H}_{17} \# 6$, where $\left.\mathrm{i}=1,2, \ldots, 7\right)$.

n-propylcyclohexane $+\mathrm{H} \rightleftharpoons \mathrm{RCi}-\mathrm{C}_{9} \mathrm{H}_{17} \# 6+\mathrm{H}_{2}$ where $\mathrm{i}=1,2, \ldots, 7$,

$n$-propylcyclohexane $+\mathrm{OH} \rightleftharpoons \mathrm{RCi}-\mathrm{C}_{9} \mathrm{H}_{17} \# 6+\mathrm{H}_{2} \mathrm{O}$.

The cyclohexanepropyl radicals are decomposed to propenylcyclohexane (pchei where $\mathrm{i}=1$, $2, \ldots, 6)$ and $\mathrm{HO}_{2}$ through oxidation reactions (RCi- $\mathrm{C}_{9} \mathrm{H}_{17} \# 6+\mathrm{O}_{2} \rightleftharpoons$ pchei $+\mathrm{HO}_{2}$ ). A ß-scission of cyclohexanepropyl radical involves decomposition of $\mathrm{C}-\mathrm{H}$ bond on the alkyl chain and on the cycle releasing $\mathrm{H}$-atom $\left(\mathrm{RCi}-\mathrm{C}_{9} \mathrm{H}_{17} \# 6 \rightleftharpoons\right.$ propenylcyclohexane $\left.+\mathrm{H}\right)$.

The cyclohexanepropyl radicals also isomerizes by the following reactions,

$$
\begin{aligned}
& \mathrm{RC} 5-\mathrm{C}_{9} \mathrm{H}_{17} \# 6 \rightleftharpoons \mathrm{RC} 2-\mathrm{C}_{9} \mathrm{H}_{17} \# 6, \\
& \mathrm{RC} 7-\mathrm{C}_{9} \mathrm{H}_{17} \# 6 \rightleftharpoons \mathrm{RC} 2-\mathrm{C}_{9} \mathrm{H}_{17} \# 6, \\
& \mathrm{RC} 4-\mathrm{C}_{9} \mathrm{H}_{17} \# 6 \rightleftharpoons \mathrm{RC} 1-\mathrm{C}_{9} \mathrm{H}_{17} \# 6, \\
& \mathrm{RC} 5-\mathrm{C}_{9} \mathrm{H}_{17} \# 6 \rightleftharpoons \mathrm{RC} 1-\mathrm{C}_{9} \mathrm{H}_{17} \# 6, \\
& \mathrm{RC} 6-\mathrm{C}_{9} \mathrm{H}_{17} \# 6 \rightleftharpoons \mathrm{RC} 1-\mathrm{C}_{9} \mathrm{H}_{17} \# 6, \\
& \text { RC6- } \mathrm{C}_{9} \mathrm{H}_{17} \# 6 \rightleftharpoons \mathrm{RC} 3-\mathrm{C}_{9} \mathrm{H}_{17} \# 6, \\
& \text { RC7- } \mathrm{C}_{9} \mathrm{H}_{17} \# 6 \rightleftharpoons \mathrm{RC} 3-\mathrm{C}_{9} \mathrm{H}_{17} \# 6 .
\end{aligned}
$$

Figure 9 shows rate of decomposition analysis of $n$-propylcyclohexane in the mixture of GtL $+50 \%$ naphthenic cut-air at $\varphi=1.0$. The mixture is at $473 \mathrm{~K}$ initial temperature and 1 bar pressure. In the flame front when about $20 \%$ of the initial fuel is consumed, the $n$-propylcyclohexane decomposes to cyclohexanepropyl radicals via $\mathrm{H}$-abstraction reactions. 
At given condition, the $\mathrm{RCi}-\mathrm{C}_{9} \mathrm{H}_{17} \# 6$ further oxidizes and forms propenylcyclohexane (pchei) and is also consumed by isomerization reactions. The propenylcyclohexane is decomposed to nonadienyle radical (cyc- $\mathrm{C}_{9} \mathrm{H}_{15}$ ) by $\mathrm{H}$-abstraction reactions. This cyc- $\mathrm{C}_{9} \mathrm{H}_{15}$ reacts further by $\mathrm{C}-\mathrm{C}$ bond scission decomposes to smaller hydrocarbons, mainly to $\mathrm{C}_{2} \mathrm{H}_{4}$.

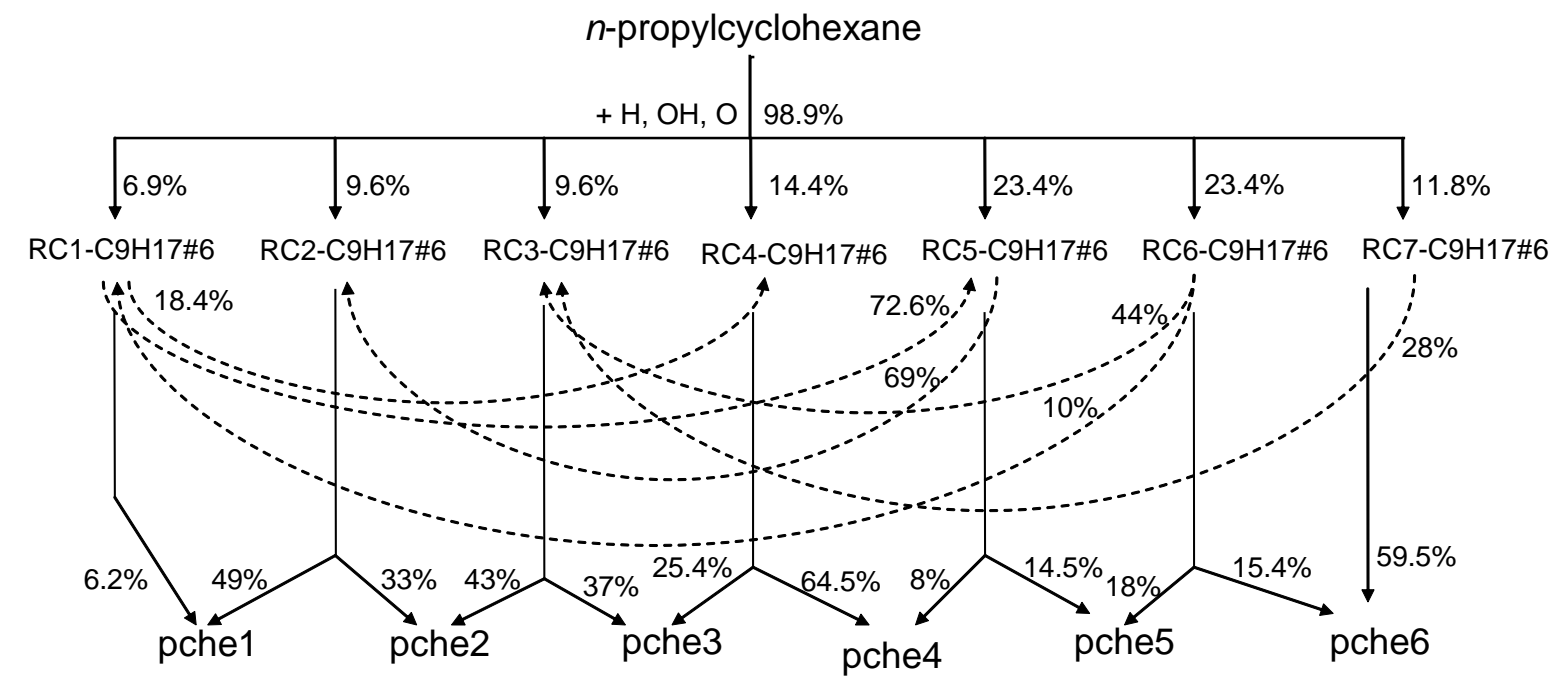

Fig. 9. Rate of production analysis: Schematic showing the consumption of $n$-propylcyclohexane in the GtL $+50 \%$ naphthenic cut-air fuel mixture at $\mathrm{HAB}=0.08 \mathrm{~cm}(\varphi=$ 1.0, $p=1$ bar, $T_{0}=473 \mathrm{~K}$ ).

\section{Results and Discussion}

The measurements of burning velocities of the four synthetic fuel-air mixtures exploiting the cone angle method are presented, for ambient pressure and different fuel-air mixtures, at a preheat temperature of $473 \mathrm{~K}$. A detailed reaction model [22-23, 31] is applied to predict the laminar flame speeds of measured mixtures. A surrogate, with a limited number of compounds, is used with known kinetic sub models to represent the fuel-air mixtures as discussed above (details given in Table 1). Finally, the measured burning velocities are compared with those of a Jet A-1, measured earlier [20].

\subsection{The Burning Velocity of GtL-air Mixtures}

The burning velocities of the neat GtL-air mixtures are measured for a fuel equivalence ratio $\varphi$ between 1.0 and 1.4 , at a preheat temperature $T_{0}=473 \mathrm{~K}$, and ambient pressure. Figure 10 shows the comparison of measured burning velocities of the GtL-air mixture (solid symbols) with the predicted laminar flame speed (open symbols, curve). The 
uncertainty limits of the experimentally derived values are also given. Two different nozzles with a different diameter were chosen to get a stable conical flame over a wide range of equivalence ratios. For stabilizing a flame at wide range of fuel-air ratios, nozzles of different diameters are used. The higher the fuel-air ratio, the smaller is the nozzle diameter. In general, the influence of flame stretch on burning velocity is higher with nozzle of smaller diameter. In the fuel rich regime, the flame gets unstable at certain fuel-air ratio. The measured and the computed velocities are in excellent agreement over the whole stoichiometric range. The trends as well as the main features are well captured by the predictions. The maximum velocities are found around $\varphi=1.0-1.1$. The error bars represents the standard deviation. Also for clarity, the value at $\varphi=1.4$ is added to demonstrate the high increase in the uncertainty due to the increased instability of the flame contour.

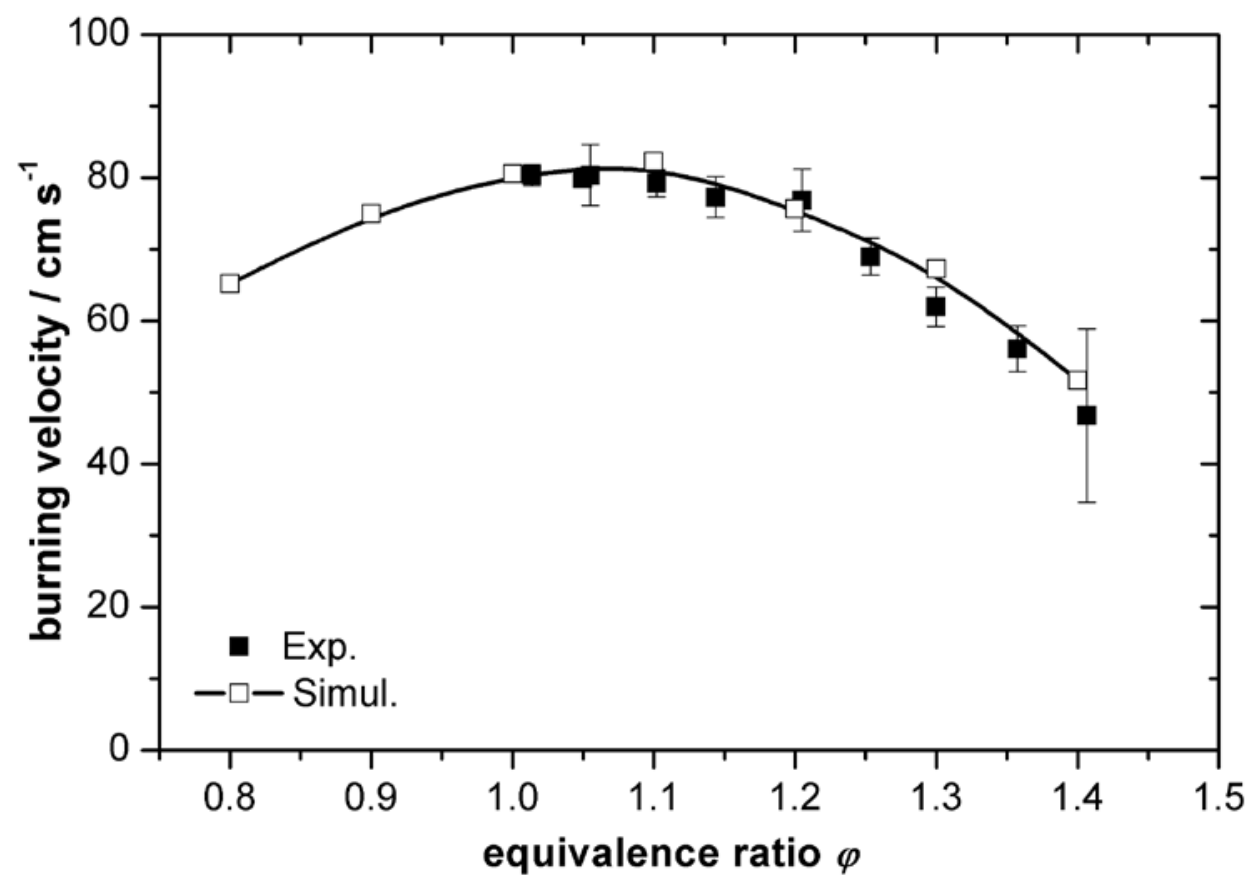

Fig. 10. Comparison between measured burning velocity (solid symbols) and predicted laminar flame speed (open symbols and line) for GtL-air mixtures at 1 bar pressure and $473 \mathrm{~K}$ preheat temperature. Calculations with the detailed reaction model [22-23, 31].

A sensitivity analysis (normalized local sensitivity) is performed with respect to the laminar flame speed of the mixtures studied, for a fuel lean (Fig. 11, upper bar), stoichiometric (Fig. 11, central bar), and a fuel rich mixture (Fig. 11, lower bar). The flame speeds are mostly sensitive to the kinetics of the main chain branching reaction $\mathrm{H}+\mathrm{O}_{2} \rightleftharpoons$ $\mathrm{OH}+\mathrm{O}$. The reaction governing heat release $\mathrm{CO}+\mathrm{OH} \rightleftharpoons \mathrm{CO}_{2}+\mathrm{H}$ is also rate limiting, sensitivity is approximately $50 \%$ compared to the $\mathrm{H}+\mathrm{O}_{2} \rightleftharpoons \mathrm{OH}+\mathrm{O}$ reaction. Other reactions 
pertaining to the H/O- and CO-sub-systems are less sensitive. In addition, reactions of $\mathrm{C}_{2} \mathrm{H}_{\mathrm{x}}$ and $\mathrm{C}_{3} \mathrm{H}_{\mathrm{x}}$ species resulting from combustion of large alkanes show some sensitivity to the flame speed.

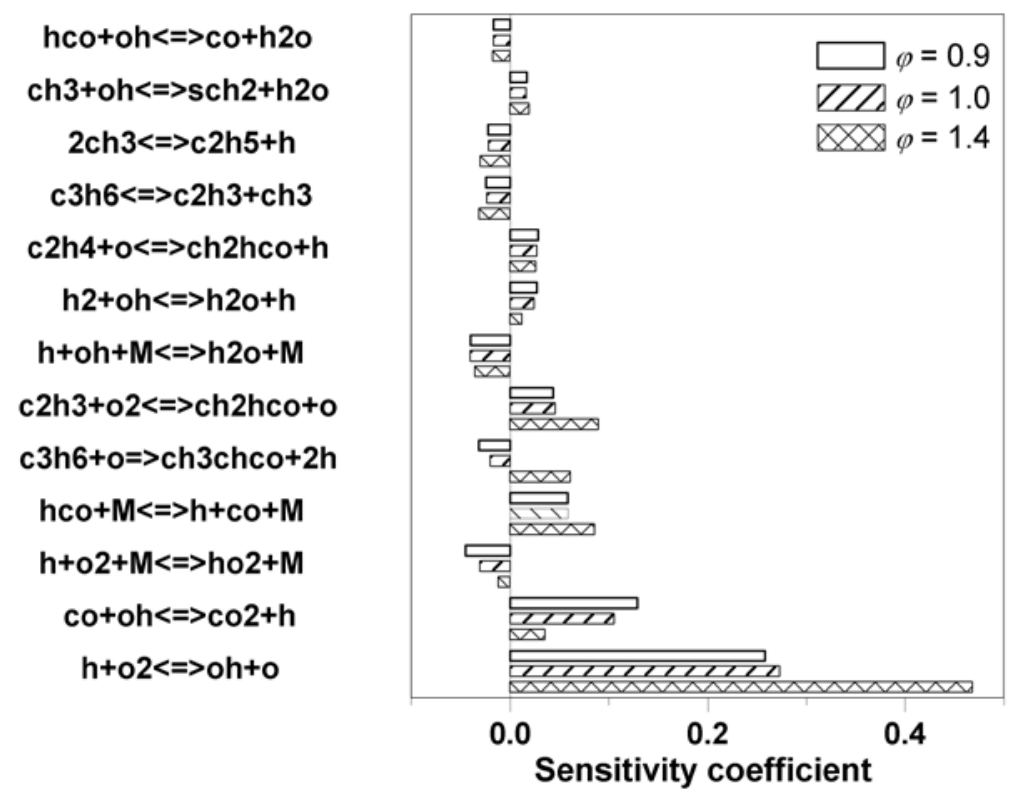

Fig. 11. GtL-air mixtures: Sensitivity analysis of laminar flame speed, $p=1$ bar, $T_{0}=$ $473 \mathrm{~K}, \varphi=0.9,1.0$, and 1.4. Calculations with the detailed reaction model [22-23, 31].

\subsection{The Burning Velocity of GtL+20\% 1-Hexanol-air Mixtures}

Values of the burning velocities of the GtL+20\% 1-hexanol-air mixture, also measured for $p=1 \mathrm{~atm}$, are shown in Fig. 12 (solid symbols). The measurements are performed for equivalence ratios $\varphi$ between 1.0 and 1.3. As expected, the maximum of the burning velocities is observed in the slightly fuel-rich regime, between $\varphi=1.0$ and $\varphi=1.1$. The trends and the main features are reproduced by the calculations and are mostly within the uncertainty limit of the measurements. The predictions (open symbols and line) show a good agreement with the experimental results. However, for lower $\varphi$ values, the experimental data are underpredicted, whereas at larger $\varphi$ values, the predicted data are slightly larger. The predicted laminar flame speeds at higher equivalence ratio $\varphi=1.3$ deviate from the experiments. For higher equivalence ratios $(\varphi>1.3)$, as well as for lean fuel-air mixtures, it was not possible to stabilize conical flames. 


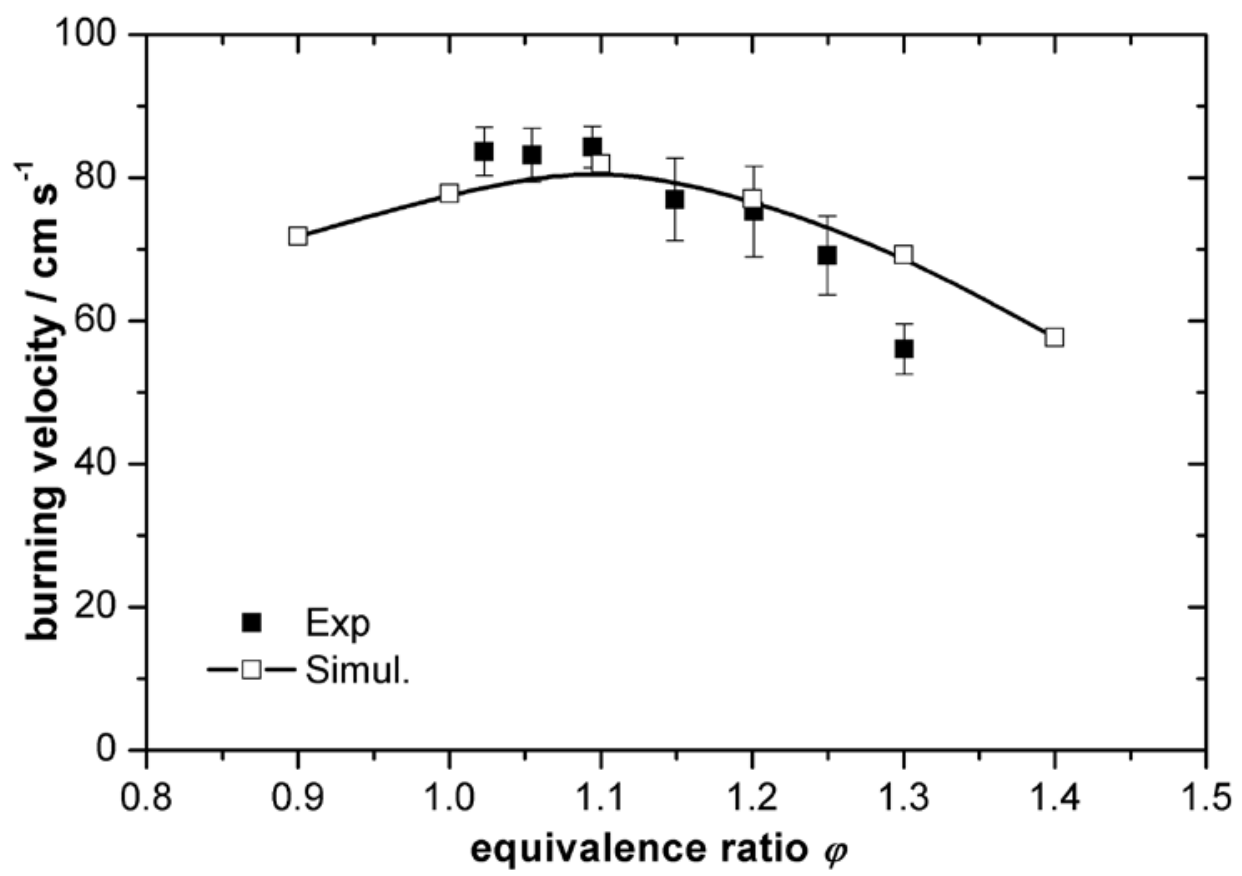

Fig. 12. GtL $+20 \%$ 1-hexanol-air mixtures: Comparison between measured burning velocity (solid symbol) and predicted laminar flame speed (open symbols and line) for $p=1$ bar and $T_{0}=473 \mathrm{~K}$. Calculations with the detailed reaction model [22-23, 31].

The most dominant reactions determining the burning velocity of the GtL $+20 \% 1$-hexanol fuel are the basic chain branching step $\mathrm{H}+\mathrm{O}_{2} \rightleftharpoons \mathrm{OH}+\mathrm{O}$ and reactions of the $\mathrm{CO}$ sub mechanism ( $\mathrm{CO}+\mathrm{OH} \rightleftharpoons \mathrm{CO}_{2}+\mathrm{H}$ and $\left.\mathrm{HCO}+\mathrm{M} \rightleftharpoons \mathrm{H}+\mathrm{CO}+\mathrm{M}\right)$, similar to the sensitivity shown for GtL-air mixture in Fig. 11. In addition, for pure component 1-hexanol-air mixture, the flame velocity is again dependent on the main branching step and CO sub mechanism rather than on hexanol specific reactions. This can be seen in Fig. 13 where the sensitivity is shown for stoichiometric and rich mixture at the position in flame where about $20 \%$ of the fuel is consumed. 


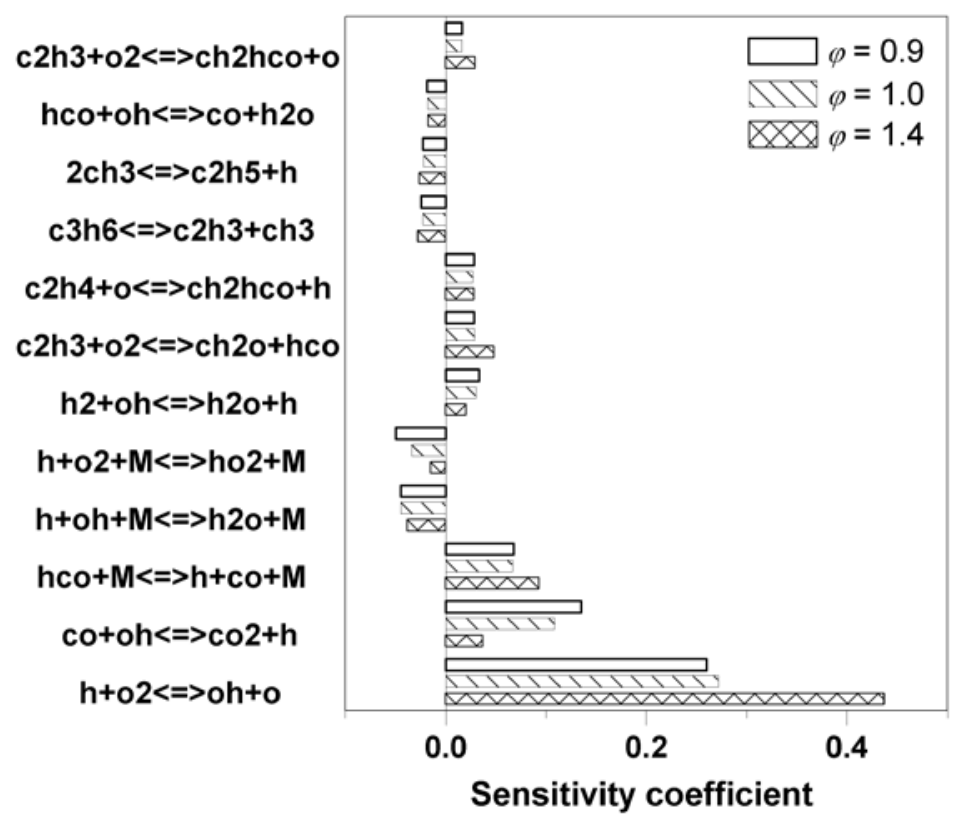

Fig. 13. 1-Hexanol-air mixtures at $\varphi=0.9,1.0$, and 1.4: Sensitivity analysis of laminar flame speed, $p=1$ bar, $T_{0}=473 \mathrm{~K}$. Calculations with the detailed reaction model [22-23, 31].

\subsection{The Burning Velocity of GtL+50\% Naphthenic Cut-air Mixtures}

The burning velocity of a mixture of GtL and $50 \% n$-propylcyclohexane-air is shown in Fig. 14. The measurements are done for equivalence ratios $\varphi$ between 1.0 and 1.45. The predictions (open symbols with line) show reasonable agreement with the experimental results. The trends and the main features are well captured by the calculations. However, the calculated laminar flame speeds for $\varphi=1.25$ to 1.35 is slightly higher than the measurements. For higher equivalence ratios $(\varphi>1.4)$, as well as for lean fuel-air mixtures, it was not possible to stabilize flames with a good conical shape; thus, the shown data point exhibits a relatively large uncertainty. For lower $\varphi$ values, the experimental data seems to be slightly higher than the predicted ones. It is interesting to note that the maximum of the burning velocities is shifted towards the more fuel-rich regime. This can be seen from the experimental data (about $\varphi=1.15$ ) as well as from the predicted ones (around $\varphi=1.15$ and $\varphi=1.2)$. 


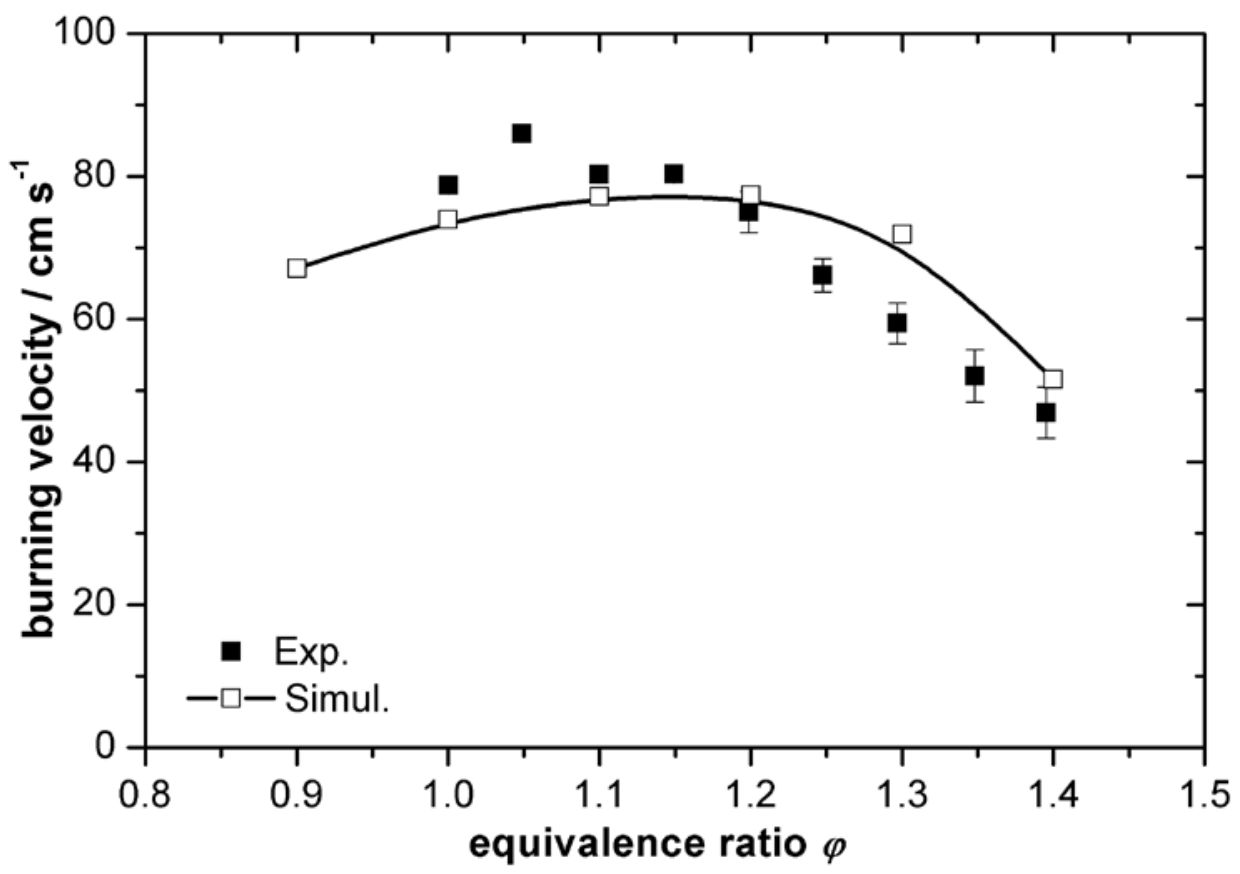

Fig. 14. GtL $+50 \%$ naphthenic cut-air mixtures: Comparison between predicted burning velocity (open symbols and line) and measured laminar flame speed (solid symbols) for $p=1$ bar and $T_{0}=473 \mathrm{~K}$. Calculations with the detailed reaction model [22-23, 31].

The overall oxidation of GtL $+50 \%$ naphthenic cut-air mixtures is mainly driven by $n$ decane and therefore the results of sensitivity analysis is similar to the ones for the GtL-air and the GtL+20\% 1-hexanol-air mixtures. Thus, to see the influence of $n$ propylcyclohexane on the flame velocity, we checked the reactions influencing the flame velocity in the pure propylcyclohexane-air mixture when about $20 \%$ of the fuel is consumed (Fig. 15). Again, the main branching step remains most important. However, few reactions pertaining to the $n$-propylcyclohexane system showed very small sensitivity. As seen in the surrogates section, these reactions are important in the formation of intermediates such as ethylene and methyl radicals. 


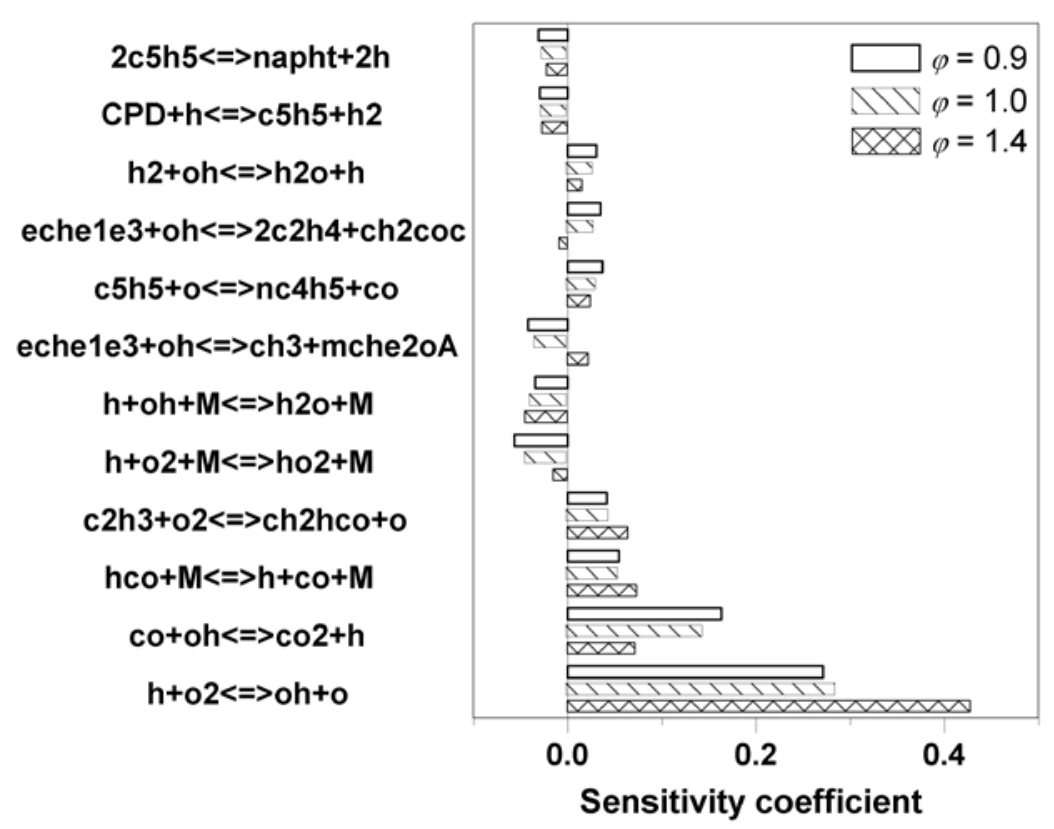

Fig. 15. $n$-Propylcyclohexane-air mixtures at $\varphi=0.9,1.0$, and 1.4: Sensitivity analysis of laminar flame speed, $p=1$ bar, $T_{0}=473 \mathrm{~K}$. Calculations with the detailed reaction model [2223, 31].

\subsection{The Burning Velocity of CtL-air Mixtures}

The measured burning velocity of the CtL-air mixtures studied are between 50 and $80 \mathrm{~cm} \mathrm{~s}^{-1}$ for fuel equivalence ratios ranging from 0.95 to 1.35 . Figure 16 shows the comparison between measured and predicted flame speeds. A reasonable agreement is obtained with the predicted flame speeds values being slightly smaller for lean mixtures whereas the values are larger in the fuel rich region. The maximum of the measured burning velocity occurs at a slightly smaller value of the equivalence ratio ( $\varphi$ between 1.0 and 1.1) than the predicted laminar flame speeds which peak at $\varphi \approx 1.1$. 


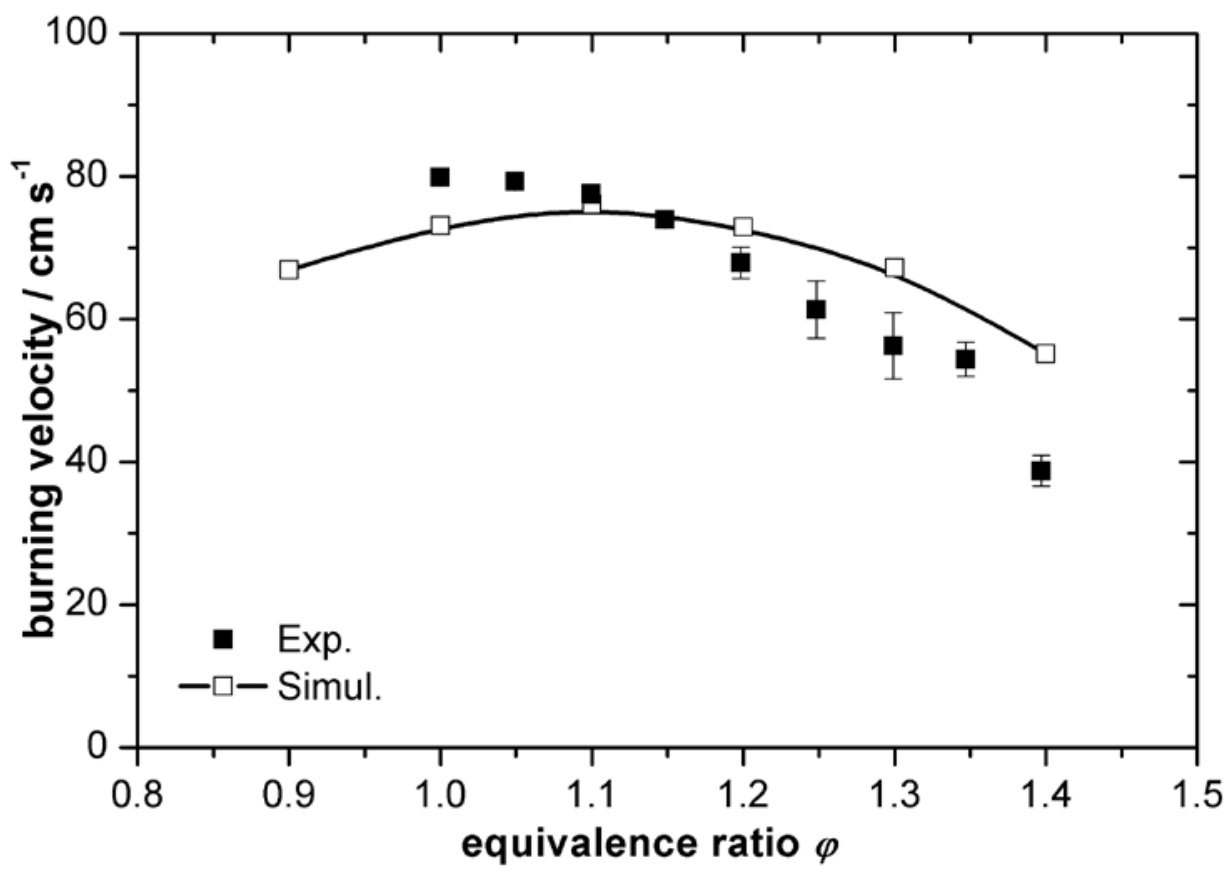

Fig. 16. CtL-air mixtures: Comparison between predicted laminar flame speed (open symbols and line) and measured burning velocity (solid symbols) for $p=1$ bar and $T_{0}=473$ K. Calculations with the detailed reaction model [22-23, 31].

The sensitivity analysis performed with respect to laminar flame speed of CtL-mixtures (Fig. 17) is not different from the GtL-air mixtures where the major component is $n$-decane. However if we consider pure $n$-propylbenzene, few reactions related to the toluene or propylbenzene consumption show some sensitivity as they are involved in radical formation (Fig. 18), though their influence remains negligible compared to the main branching step.
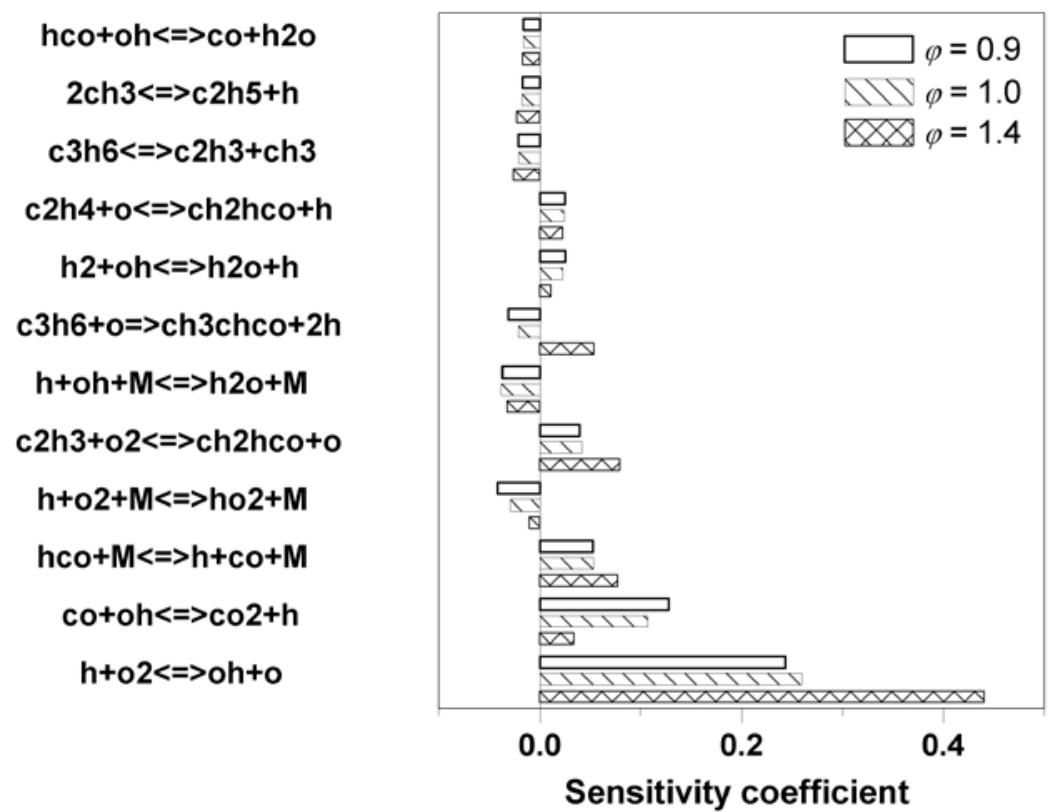

Fig. 17. CtL-air-mixtures: Sensitivity analysis of the laminar flame speed, $p=1$ bar, $T_{0}=473$ 
$\mathrm{K}, \varphi=0.9,1.0$, and 1.4. Calculations with the detailed reaction model [22-23, 31].

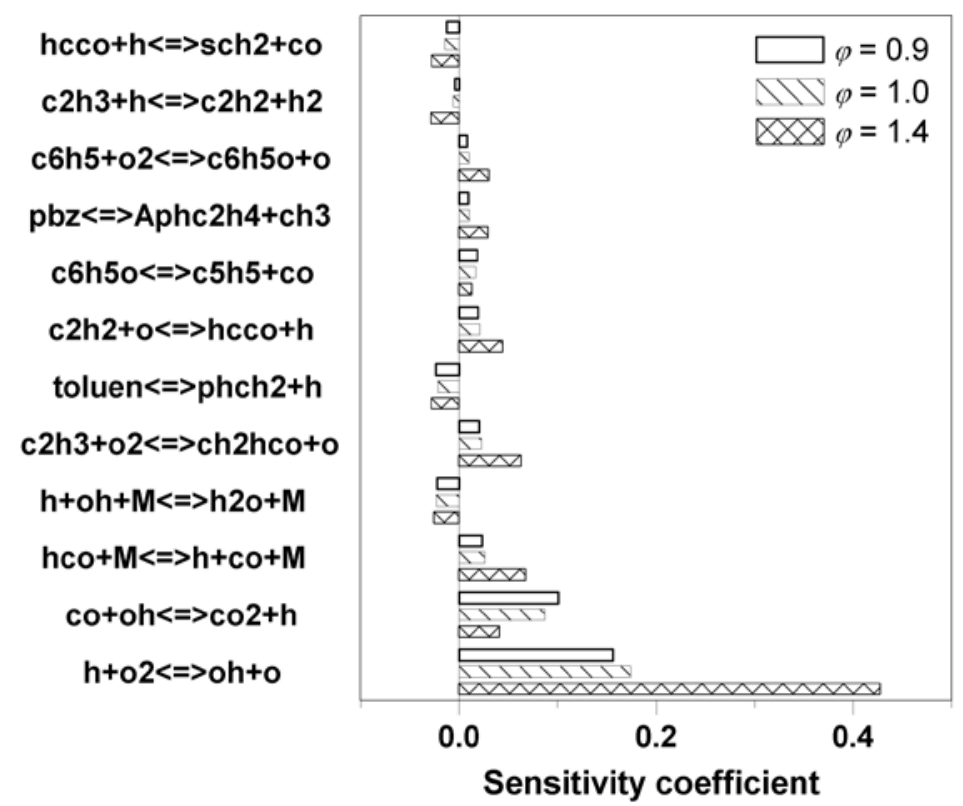

Fig. 18. $n$-Propylbenzene-air mixtures at $\varphi=0.9,1.0$, and 1.4: Sensitivity analysis of the laminar flame speed, $p=1$ bar, $T_{0}=473 \mathrm{~K}$. Calculations with the detailed reaction model [2223, 31].

\subsection{Comparison between the Synthetic Fuels and Jet A-1}

Figure 19 shows the experimentally determined burning velocities and predicted values of the laminar flame speed of various fuel-air mixtures as a function of the equivalence ratio $\varphi$, together with experimental data of a Jet A-1 fuel (stars) measured earlier by Eberius in a similar burner test rig [20]. For the equivalence ratio $\varphi$ between 1.1 and 1.4, all the measured burning velocities are similar to the velocities of the four synthetic (GtL and CtL) fuels studied. At $\varphi<1.1$, some deviation is seen where the synthetic fuel velocities are lower than the ones of Jet A-1. This comparison to Jet A-1 clearly shows the suitability of the fuels investigated defining the burning velocity as a measure for the heat release. 


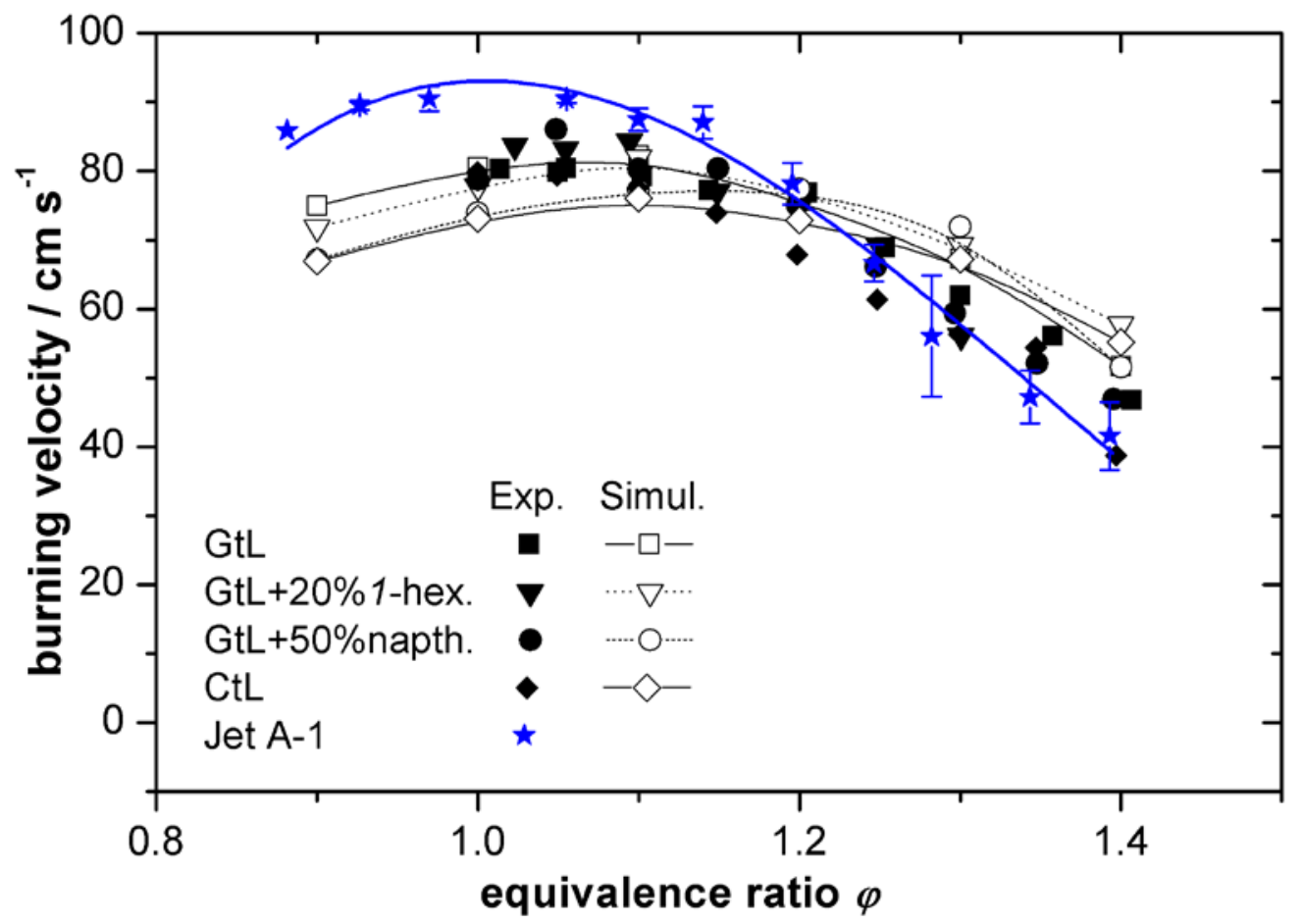

Fig. 19. Comparison between predicted laminar flame speed (open symbols and line) and measured burning velocity (solid symbols) for Jet A-1-air [20], with GtL and CtL mixtures. The mixtures are at 1 bar pressure and $473 \mathrm{~K}$ preheat temperature. Calculations with the detailed reaction model [22-23, 31].

The calculated laminar flame speeds of the surrogate components - $n$-decane, iso-octane, 1-hexanol, n-propylbenzene, and n-propylcyclohexane - are displayed in Fig. 20, for the same temperature and pressure the alternative fuels were studied. It can be seen that 1 -hexanol, $n$-propylbenzene, and $n$-decane, have similar burning velocities whereas isooctane has the lowest values, being about 1.5 times lower. Interesting to note is the shape of the calculated values for $n$-propylcyclohexane: the laminar flame speed is increasing with increasing equivalence ratio, from $\varphi=0.9$ till $\varphi=1.3$, with the maximum value predicted for $\varphi$ $=1.3$ for all other surrogate components, the curves peak around $\varphi=1.1$.

The sensitivity analysis has shown that the overall oxidation of all mixtures is driven by the main component $n$-decane; therefore, the flame velocities of all the GtL- and CtLmixtures are similar and small variations are due to the difference in the second major component flame speeds. 


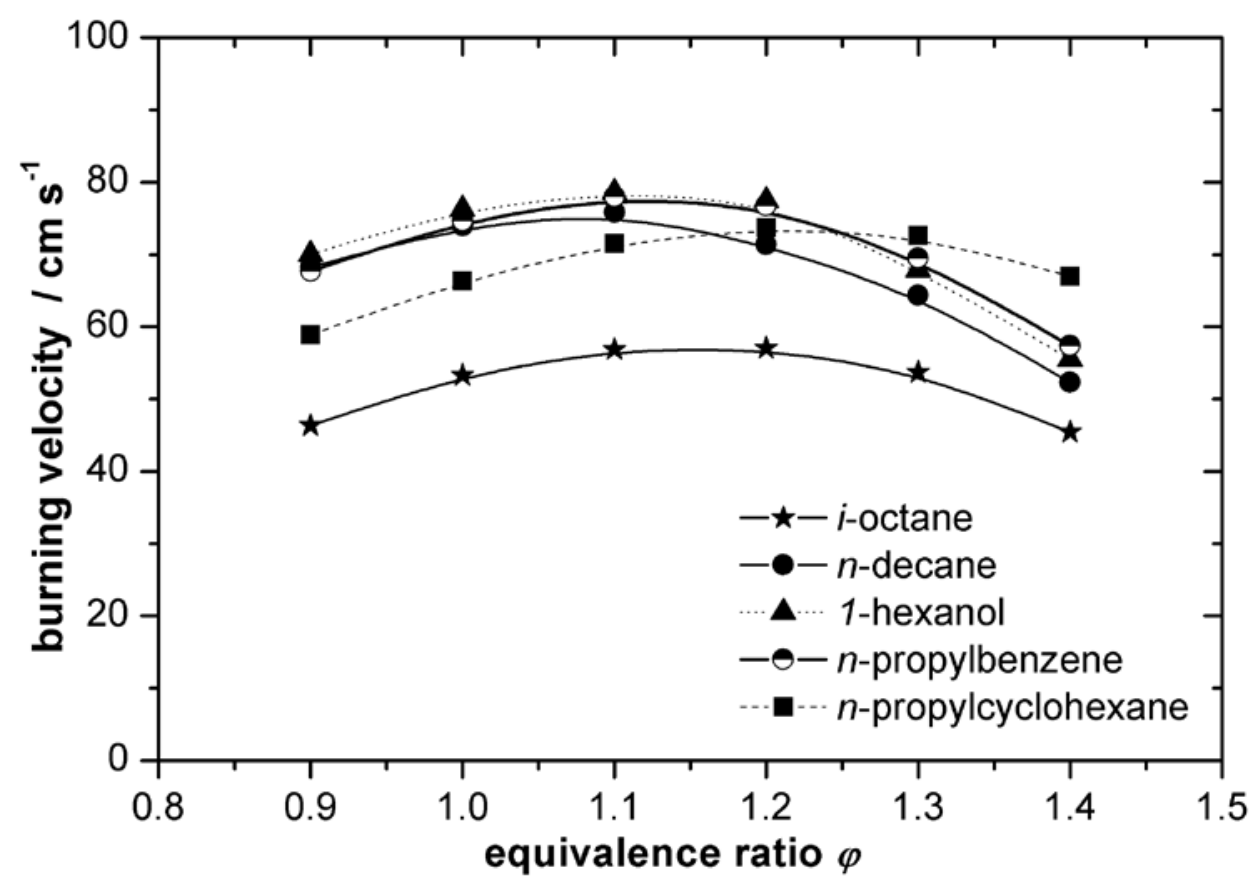

Fig. 20. Predicted laminar flame speed for the five components of the surrogate; $T_{0}=473 \mathrm{~K}$, $p=1$ bar. Calculations with the detailed reaction model [22-23, 31].

\section{Conclusions}

The burning velocities of three GtL-air synthetic fuel-air mixtures (100\% GtL representing a Fischer-Tropsch SPK, GtL+20\% 1-hexanol, and GtL+50\% naphthenic cut) and a CtL fuel - representing a FSJF - were measured. The different fuel-air mixtures were studied at ambient pressure and at a preheat temperature of $473 \mathrm{~K}$, due to their high boiling points and to ensure that all of the several constituents of the fuels were evaporated. The burning velocities of the vaporized liquid fuels were determined by applying the cone angle method. Flames of a conical shape suitable for determining burning velocities were stabilized within a limited equivalence ratio $\varphi$, ranging from 0.9 to 1.4. The flame velocities are also predicted by the detailed mechanism. Therefore, the predictive capability of the used detailed reaction model was demonstrated. A good agreement is found between measured burning velocity and predicted flame speeds for all four fuels studied.

Our findings support the potential of the investigated fuel mixtures to serve as alternative aviation fuels. The information on the laminar flame speed can have some impact on the jet turbine burner design and the combustor as the flame will be stabilized at different heights above the burner depending on the flame length and therefore heat load of the walls or the recirculation zones may change. In the future, experiments will also be extended to higher pressures. 


\section{Acknowledgements}

The authors thank C. Wahl and M. Kapernaum for their analysis of the fuels compositions. The authors are grateful to P. Dagaut from CNRS, ICARE Orléans, France, for providing us with his reaction model. This work was performed within the EUFP7 project ALFA-BIRD: EUFP7/2007-2013, grant agreement no 213266.

\section{References}

[1] Dagaut $\mathrm{P}$, Cathonnet $\mathrm{M}$. The ignition, oxidation, and combustion of kerosene: A review of experimental and kinetic modelling. Prog Energ Combust 2006;32:48-92.

[2] Hileman JI, Stratton RW, Donohoo PE. Energy Content and Alternative Jet Fuel Viability. J Propul Power 2010;26:1184-95.

[3] Unnikrishnan M. IEA: Jet fuel demand to grow briskly through 2012. Aviation Daily; 2007, http://www.aviationweek.com.

[4] ASTM Standard D1655, www.astm.org.

[5] IPPC Intergovernmental Panel on Climate Change, 2007:"Climate Change 2007: Mitigation of Climate Change", http://www.ipcc.ch/publications and data/publications ipcc fourth assessment report wg3 report mitigation of climate change.htm.

[6] Braun-Unkhoff M, Le Clercq P, Aigner M. Alternative fuels and biofuels for aircraft development. Proceedings of 17th European Biomass Conference and Exhibition, Hamburg, Germany; 2009.

[7] AIREG, http://newsroom.lufthansa.com/news/research-institutes-and-industry-found-aviation-initiative-for-renewableenergy-in-germany-aireg.

[8] World Resources Institute, "Beginner's Guide to Aviation Biofuels". IATA, May 2009; http://www.enviro.aero/.

[9] ACARE: "Acare addendum to the strategic research agenda". http://www.acare4europe.com/docs/ACARE 2008 Addendum.pdf; 2008.

[10] http://www.caafi.org/.

[11] Blakey S, Rye L, Wilson CW. Aviation gas turbine alternative fuels: A review. Proc Combust Inst 2011;33:2863-85.

[12] Moses CA, Roets PNJ. Properties, characteristics, and combustion performance of Sasol fully synthetic jet fuel. Proceedings of ASME Turbo Expo 2008: Power for Land, Sea, and Air (GT2008); 2008 June 9-13; Berlin, Germany: Paper No.: GT2008-50845.

[13] Qatar Airlines, first commercial scheduled flight with GtL; October 2009.

[14] CEO Lufthansa; announced May 2010.

[15] burnFAIR, http://presse.lufthansa.com/en/news-releases/singleview/archive/2010/november/29/article/1828.html.

[16] ALFA-BIRD: "Alternative Fuels and Biofuels for Aircraft", EUFP7/2007-2013, grant agreement no²13266; http://www.alfabird.eu-vri.eu.

[17] SWAFEA: Sustainable Way for Alternative Fuels and Energy for Aviation, EU, DGTren, co-ordinator: ONERA, France.

[18] Kick Th, Kathrotia T, Braun-Unkhoff M, Riedel U. An experimental and modeling study of laminar flame speeds of alternative aviation fuels. Proceedings of ASME Turbo Expo 2011: Power for Land, Sea, and Air (GT2011); 2011 June 610; Vancouver, Canada: Paper No.: GT2011-45606.

[19] Kick Th, Kathrotia T, Braun-Unkhoff M, Herbst J, Naumann C, Riedel U. An investigation of laminar flame speeds of alternative aviation fuels: an experimental and modeling study. Proceedings of 5th European Combustion Meeting 2011; Paper No.: 269.

[20] Eberius H. DLR Stuttgart, within Computational fluid dynamics for combustion (CFD4C), EU-project, No. G4RD-CT-1999$00075 ; 1997$.

[21] Braun-Unkhoff M, Kick Th, Frank P, Aigner M. An investigation on laminar flame speed as part of needed combustion characteristics of biomass-based syngas fuels. Proceedings of ASME Turbo Expo 2007: Power for Land, Sea, and Air (GT2007); 2007 May 14-17; Montreal, Canada: Paper No.: GT2007-27479.

[22] Togbe C, Dagaut P, Mze-Ahmed A, Dievart P, Halter F, Foucher F. Experimental and Detailed Kinetic Modeling Study of 1Hexanol Oxidation in a Pressurized Jet-Stirred Reactor and a Combustion Bomb. Energ Fuel 2010;24:5859-75.

[23] Mze-Ahmed A, Hadj-Ali K, Dievart P, Dagaut P. Kinetics of oxidation of a synthetic jet fuel in a Jet-stirred reactor: Experimental and modeling study. Energ Fuel 2010;24:4904-11.

[24] Neste Oil, http://www.nesteoil.com/default.asp?path=1,41,11991,12243,17555.

[25] UOP Honeywell, http://www.uop.com/honeywells-uop-renewable-jet-fuel-technology-military-testing-certification/.

[26] ASTM D7655, addendum to ASTM Standard D1655, ASTM D7566 is a new specification for certifying a $50 \%$ blend of Jet A-1 and SPK produced from biomass using a Fischer Tropsch process www.astm.org.

[27] Bogers P. Shell Global Solutions Downstream (UK), within ALFA-BIRD.

[28] Böhm H, Braun-Unkhoff M. Numerical study of the effect of oxygenated blending compounds on soot formation in shock tubes. Combust Flame 2008;153:84-96.

[29] Jeuland N. IFP Energies Nouvelles, Rueil-Malmaison (France), within ALFA-BIRD.

[30] Viljoen C. Sasol, South Africa, within ALFA-BIRD.

[31] Dagaut P. ICARE, Orleans (France), within ALFA-BIRD.

[32] Wahl C, Kapernaum M, Lützow M. ALFABIRD - DLR Stuttgart; 2010.

[33] Andrews GE, Bradley D. Determination of burning velocites: A critical review. Combust Flame 1972;18:133-53.

[34] Eberius H, Kick Th. Stabilization of premixed, conical methane flames at high pressure. Ber Bunsenges Phys Chem 1992; $96: 1416-19$

[35] Aschenbrenner H, Nieken U. Institut für Chemische Verfahrenstechnik (ICVT), University Stuttgart, Germany.

[36] Edwards T, Atria JV. Thermal Stability of High-Temperature Fuels. Proceedings of ASME Turbo Expo 1997: Power for Land, Sea, and Air (GT1997); 1997 June 2-5; Orlando, Florida, USA: Paper No.: GT1997-97143. 
[37] Law CK. Dynamics of stretched flames. Proc Combust Inst 1988;22:1381-1402.

[38] Rallis CJ, Garforth AM. The determination of laminar burning velocity. Prog Energ Combust Sci 1980;6:303-29.

[39] Wu C, Law CK. On the determination of laminar flame speeds from stretched flames. Proc Combust Inst 1985;20:1941-49.

[40] Markstein GH. Non-steady flame propagation. New York: Pergamon; 1964, p22.

[41] Vukadinovic $V$, Habisreuther $P$, Zarzalis N. Experimental study on the influence of pressure and temperature on the burning velocity and Markstein Number of Jet A-1 kerosene. Proceedings of ASME Turbo Expo 2010: Power for Land, Sea, and Air (GT2010); 2010 June 14-18; Glasgow, UK: Paper No.: GT2010-22535.

[42] Edwards T, Maurice LQ. Surrogate mixtures to represent complex aviation and rocket fuels. J Propul Power 2001;17:46166.

[43] Dagaut P. On the kinetics of hydrocarbons oxidation from natural gas to kerosene and diesel fuel. Phys Chem Chem Phys 2002;4:2079-94.

[44] Dagaut P, El-Bakali A, Ristori A. The combustion of kerosene: Experimental results and kinetic modelling using 1- to 3component surrogate model fuels. Fuel 2006;85:944-56.

[45] Le Cong T, Dagaut P. Kinetics of Natural Gas, Natural Gas/Syngas Mixtures Oxidation and Effect of Burnt Gas Recirculation: Experimental and Detailed Modeling. Proceedings of ASME Turbo Expo 2007: Power for Land, Sea, and Air (GT2007); 2007 May 14-17; Montreal, Canada: Paper No.: GT2007-27146.

[46] Gauthier BM, Davidson DF, Hanson RK. Shock tube determination of ignition delay times in full-blend and surrogate fuel mixtures. Combust Flame 2004;139:300-11.

[47] Colket M, Edwards T, Williams S, Cernansky NP, Miller DL, Egofopoulos F, et al. Development of an experimental database and kinetic models for surrogate jet fuels. 45th AIAA Aerospace Sciences Meeting and Exhibit, 2007;AIAA-2007770.

[48] Dean AJ, Penyazkov OG, Sevruk KL, Varatharajan B. Autoignition of surrogate fuels at elevated temperatures and pressures. Proc Combust Inst 2007;31:2481-88

[49] Honnet S, Seshadri K, Niemann U, Peters N. A surrogate fuel for kerosene. Proc Combust Inst 2009;32:485-92.

[50] Skjøth-Rasmussen MS, Braun-Unkhoff M, Naumann C, Frank P. Experimental and numerical study of n-decane chemistry Proceedings of 3rd European Combustion Meeting 2003; Paper No.:12.

[51] Dagaut $\mathrm{P}$, Reuillon M, Cathonnet $\mathrm{M}$, Voisin D. High pressure oxidation of normal decane and kerosene in dilute conditions from low to high temperature. J Chim Phys 1995;92:47-76.

[52] Glaude PA, Warth V, Fournet R, Battin-Leclerc F, Scacchi G, Come GM. Modeling of the oxidation of n-octane and ndecane using an automatic generation of mechanisms. Int J Chem Kinet 1998;30:949-59.

[53] Olchanski E, Burcat A. Decane oxidation in a shock tube. Int J Chem Kinet 2006;38:703-13.

[54] Bikas G, Peters N. Kinetic modelling of $n$-decane combustion and autoignition: Modeling combustion of $n$-decane. Combust Flame 2001;126:1456-75.

[55] You X, Egolfopoulos FN, Wang $\mathrm{H}$. Detailed and simplified kinetic models of $n$-dodecane oxidation: the role of fuel cracking in aliphatic hydrocarbon combustion. Proc Combust Inst 2009;32:403-10.

[56] Fournet R, Battin-Leclerc F, Glaude PA, Judenherc B, Warth V, Côme GM, et al. The gas-phase oxidation of nhexadecane. Int J Chem Kinet 2001;33:574-86.

[57] Braun-Unkhoff M, Frank P, El-Bakali A, Dagaut P. Detailed Kinetic Reaction Mechanism for Kerosene Oxidation at Atmospheric Pressure. 16 ${ }^{\text {th }}$ Int Symp Gas Kinet 2000.

[58] Steil U, Braun-Unkhoff M, Frank P, Aigner M. An experimental and modeling study on the auto ignition of kerosene and surrogate fuel mixture. 46th AIAA Aerospace Sciences Meeting and Exhibit, 2008;AIAA-2008-0973.

[59] Naik CV, Puduppakkam KV, Modak A, Wang C, Meeks E. Validated F-T Fuel Surrogate Model for Simulation of Jet-Engine Combustion. Proceedings of ASME Turbo Expo 2010: Power for Land, Sea, and Air (GT2010); 2010 June 14-18; Glasgow, UK: Paper No.: GT2010-23709.

[60] Vasu SS, Davidson DF, Hanson RK. Jet fuel ignition delay times: Shock tube experiments over wide conditions and surrogate model predictions. Combust Flame 2008;152:125-43.

[61] Kee RJ, Rupley FM, Miller JA. PREMIX, CHEMKIN-II Version 2.5b, Sandia National Laboratories, Livermore (CA), USA;1992. 